\title{
Odpowiedzialność karna za zbrodnie sądowe sędziów III Rzeszy w Niemczech Zachodnich i Wschodnich
}

\section{WPROWADZENIE}

Sędzia pozostaje pierwszoplanową postacią w pojęciu zbrodni sądowej, mimo że to oskarżający w postępowaniu sądowym prokurator uruchamiał bieg zdarzeń procesowych kończących się skazaniem podsądnego, gwałcącym elementarne poczucie sprawiedliwości ${ }^{1}$. W Republice Federalnej Niemiec nie został prawomocnie skazany żaden sędzia ani prokurator współdziałający w dokonywaniu zbrodni sądowych w służbie III Rzeszy, a przyczyny tego, że tak się stało, zostały z wielką dociekliwością badawczą $\mathrm{w}$ sferze dogmatyki i detektywistyczną skrupulatnością w ustalaniu faktów ukazane w historycznoprawnych dziełach Manfreda Görtemakera i Christofa Safferlinga, podsumowujących rozliczenie z przeszłością ${ }^{2}$. Obnażyli oni także strukturę kadrową utworzonego w 1949 r. ministerstwa sprawiedliwości w Bonn zdominowanego przez przedwojennych ministerialnych urzędników, byłych członków nazistowskich organizacji, oceniając w ten sposób ich szczególne jurystyczne kwalifikacje i zaangażowanie:

${ }^{1}$ Zagadnienie osądzenia narodowosocjalistycznych prokuratorów przedstawiono w: W. Kulesza, Odpowiedzialność karna za zbrodnie sądowe prokuratorów III Rzeszy w Niemczech Zachodnich $i$ Wschodnich, „Czasopismo Prawno-Historyczne” 2021, t. LXXIII, z. 1, s. 59 i n.

${ }^{2}$ M. Görtemaker, Ch. Safferling (red.), Die Rosenburg. Das Bundesministerium der Justiz und die NS-Vergangenheit - eine Bestandsaufnahme, Bonn 2013; M. Görtemaker, Ch. Safferling, Die Akte Rosenburg. Das Bundesministerium der Justiz und die NS-Zeit, München 2016. 
Ważniejszy od przynależności do NSDAP lub SA był fakt, że wielu pełniących funkcje kierownicze przed 1945 r. uczestniczyło, w ministerstwie narodowosocjalistycznego państwa, bezpośrednio w realizacji ,,woli Führera” (Führerwille) ${ }^{3}$.

Natomiast nowo powoływani do Justizministerium przez swoją wcześniejszą

[...] działalność w sądownictwie, w tym w sądach specjalnych (Sondergerichte) III Rzeszy, a także w sądach na „terenach okupowanych”, jak również w sądownictwie wojskowym, ponosili ciężką osobistą winę za wdrażanie i stosowanie zbrodniczych ustaw, przygotowanych w Reichsjustizministerium ${ }^{4}$.

Ustalenia cytowanych autorów skłaniają do pochylenia się nad kwestią odpowiedzialności karnej za zbrodnie sądowe dokonywane w okupowanej Polsce przez sędziów sądów specjalnych. W demokratycznych Niemczech Zachodnich nie ponieśli oni konsekwencji przestępczego naginania prawa w ferowanych przez siebie drakońskich wyrokach. Natomiast w totalitarnych Niemczech Wschodnich, w poszczególnych przypadkach, skazani zostali za sądowe morderstwa popełnione na Polakach, stanowiące w istocie prawnej zbrodnie przeciwko ludzkości.

Zarysowanie kategorii prawnych, w których ustalano ich odpowiedzialność w RFN i NRD, wymaga przedstawienia na wstępie wybranych wyroków, ilustrujących pojęcie zbrodni sądowej. Przy ich wyborze kierowano się tezami norymberskiego wyroku z 4 grudnia 1947 r. amerykańskiego Trybunału Wojskowego w sprawie prawników, który w kategoriach zbrodni przeciwko ludzkości ocenił wyroki skazujące na karę śmierci Polaków i Żydów oskarżonych przed sądami specjalnymi, decydującymi o ich losie ze względu na przynależność narodową ${ }^{5}$.

\section{ZBRODNIE SĄDOWE NA POLSKIM TERYTORIUM WŁĄCZONYM DO RZESZY}

\subsection{Uwagi wstępne}

Przedstawienie mechanizmu dokonywania zbrodni sądowych przez narodowosocjalistycznych sędziów i kwalifikacji prawnokarnej ich czynów w Republice Federalnej w kategoriach naginania prawa - w rozumieniu $§ 336 \mathrm{StGB}^{6}-$ wymaga

${ }^{3}$ M. Görtemaker, Ch. Safferling, Die Akte Rosenburg..., s. 452.

${ }^{4}$ Ibidem.

${ }^{5}$ W. Kulesza, Crimen laesae iustitiae. Odpowiedzialność karna sędziów i prokuratorów za zbrodnie sądowe wedlug prawa norymberskiego, niemieckiego, austriackiego i polskiego, Łódź 2013, s. $41 \mathrm{in}$.

${ }^{6}, \S 336$. Urzędnik, a także sędzia polubowny, który prowadząc lub rozstrzygając sprawę prawną, umyślnie (vorsätzlich) nagina prawo na korzyść albo na niekorzyść jednej ze stron, ulegnie karze ciężkiego więzienia do lat 5". Od zmiany numeracji wprowadzonej ustawą z 18 sierpnia 
posłużenia się jako przykładami wyrokami sądów specjalnych. Zadaniem tych sądów na terenach okupowanej Polski włączonych do Rzeszy jako Gdańsk - Prusy Zachodnie i Kraj Warty było współdziałanie w tępieniu „polskich elementów” i stałym terroryzowaniu niewysiedlonych do Generalnego Gubernatorstwa, albowiem przydatnych na miejscu, ,polskich sług”7. Działalność sondergerichtów miała przyczynić się do zniemczenia terytorium objętego nowymi granicami III Rzeszy, co stanowiło naczelne zadanie wszystkich jej władz ${ }^{8}$.

Poniżej streszczone zostaną trzy wyroki wydane przez sąd specjalny w Grudziądzu, ukazujące sposób wykonywania zadania eksterminacji i terroru, postawionego przez Führera narodowosocjalistycznym sędziom. Wyroki ferowane przez Sondergerich Graudenz wybrano dlatego, że we wcześniejszym opracowaniu przedstawiono wydany w Berlinie Wschodnim w 1981 r. wyrok skazujący Otte, prokuratora przy tym sądzie 9 . Przewodniczącego składom sędziowskim, które wydały drugi i trzeci z omawianych niżej wyroków, Schönfelda wyróżniał stopień naukowy doktora habilitowanego. W trzecim z prezentowanych niżej wyroków sędziowie skazali na karę śmierci oskarżonego Polaka, mimo że prokurator wnosił o wymierzenie mu kary 7 lat więzienia. Zaskakujący procesowo, w świetle morderczej determinacji prokuratora Otte, wykazanej dowodowo w procesie przeciwko niemu, był jego ekstraordynaryjny wniosek o unieważnienie wyroku skazującego Polaka.

\subsection{Polak pomagający wysiedlanym Polakom}

Wyrok Sondergerichtu w Grudziądzu z 14 stycznia 1942 r. ${ }^{10}$, wydany z powołaniem jako podstawy prawnej „rozporządzenia o gospodarce wojennej” z 1939 r., dowodzi, że status Volksdeutscha uzyskany przez wpis na volkslistę nie chronił Polaka przed karą, jeżeli zarzucono mu „zbrodniczą pomoc” udzieloną Polakom pozbawionym praw do zakupu reglamentowanego mięsa ${ }^{11}$. Na czele składu orze-

1997 r. § 339 (zamiast § 336) StGB stanowi: „Naginanie prawa. Sędzia, inny funkcjonariusz lub sędzia polubowny, który prowadząc lub rozstrzygając sprawę prawną, popełnia (schuldig macht) nagięcie prawa na korzyść albo niekorzyść jednej ze stron, podlega karze pozbawienia wolności od roku do lat pięciu".

${ }^{7}$ Szerzej: W. Kulesza, Wysiedlenia z kraju Warty (Warthegau) w świetle procesu Gauleitera Artura Greisera [w:] J. Żelazko (red.), Ludność cywilna w tódzkich obozach przesiedleńczych, Łódź 2010, s. 36 i n.

${ }^{8}$ Szerzej: W. Kulesza, Sad Specjalny (Sondergericht) $w$ Łodzi [w:] K. Stefański, J. Machut-Kowalczyk, W. Kulesza, A. Markowska, J. Wiewiórski, Gmach i jego tajemnice. Sąd Okręgowy w Łodzi, Łódź 2017, s. 60 i n.

${ }_{9}$ W. Kulesza, Odpowiedzialność..., s. 92 i n.

${ }^{10}$ Sygn. akt. 5/2 Sg KLs 66/42, Archiwum Federalne w Berlinie, DAHL - RJM IV g Nr. des Aktenbandes 2269/42.

${ }^{11} \mathrm{O}$ położeniu prawnym Polaków wpisanych na Volkslitę: W. Kulesza, Polacy wpisani na volkslistę a obowiązek stużby w Wehrmachcie $w$ świetle wyroków Sądu Specjalnego w Toruniu, „Studia Iuridica Toruniensia” 2018, t. XXIII, s. 103 i n. 
kającego stanął przewodniczący sądu specjalnego (Der Vorsitzende des Sondergerichts) Grossmann, członkami byli Landgerichtsrat Baron v.d. Osten-Sacken i Landgerichtsrat Bussejahn.

Oskarżonym w sprawie był Franz Biliński, 36-letni żołnierz zawodowy, kapral wzięty do niemieckiej niewoli 17 września 1939 r. Jakiś czas po zwolnieniu z obozu jenieckiego został on „wciągnięty” na volkslistę i pracował jako sprzedawca w sklepie mięsnym swego wuja. Po aresztowaniu przyznał się do tego, że sprzedawał „bez kartek” mięso ubogim klientom. Z akt sprawy wynika, że w postępowaniu przed sondergerichtem pogrążył go jego obrońca, podając, że Biliński miał „sprzedawać mięso ewakuowanym Polakom" (Fleisch an evakuirte Polen verkauft habe), którym nie przysługiwały kartki żywnościowe. Zdecydowało to o dalszym biegu sprawy, pomimo ustnego sprostowania tej informacji przez adwokata. Późniejsze twierdzenie, że oskarżony postępował tak ,wobec ubogich zarówno Niemców, jak i Polaków", nie polepszyło jego sytuacji w oczach sędziów sądu specjalnego. Powołali oni jako podstawę ukarania przepisy rozporządzenia o gospodarce wojennej (Kriegswirtschaftsverordnung) - $§ 1^{12} \mathrm{i} \S 242 \mathrm{StGB}^{13}$.

W uzasadnieniu wyroku napisano, że oskarżony wyłudził z gospodarki reglamentowanej przydziały na 43 i $1 / 2$ cetnary mięsa w ten sposób, że nie zapełniał zgodnie z porządkiem (nicht ordnungsmäßig) całych arkuszy kontrolnych sprzedaży mięsa, na których powinny zostać naklejone tylko aktualne w swej ważności talony na mięso, przekazywane przez uprawnionych kupujących w chwili dokonywania zakupu w sklepie. W miejsca na arkuszu, na których miały być umieszczone kartki z aktualną ważnością, oskarżony wklejał talony na mięso ze starymi, nieaktualnymi terminami przydziałów, które z tego powodu nie mogły być już ,zgodnie z porządkiem" zrealizowane. Przeterminowane talony żywnościowe, wykorzystywane przez oskarżonego, zostały skradzione w oddziale kart żywnościowych w Tłuchowie, gdzie pracował jego brat. Postępując w taki sposób, oskarżony w okresie od grudnia 1941 r. do maja 1942 r. w przekazywanych arkuszach kontrolnych w sposób zamierzony podawał fałszywe ilości mięsa sprzedanego osobom rzekomo uprawnionym do zakupu. Wyłudzone przydziały - jak napisano w aktach sprawy - pozwoliły oskarżonemu na sprzedaż mięsa nieuprawnionym, bo nieposiadającym talonów Niemcom i Polakom, co czynił jednak nie dla własnej korzyści, gdyż pieniądze za sprzedane mięso umieszczał, „bez reszty”, w kasie sklepu.

${ }^{12}$ Kriegswirtschaftsverordnung z 4.09.1939 r. (RGB1. 1939 I, s. 1069) stanowił: „§ 1. Kto surowce lub wytworzone przedmioty, należące do życiowo ważnego zapotrzebowania ludności, niszczy, ukrywa, usuwa lub porzuca i przez to złośliwie (böswillig) zagraża pokryciu tego zapotrzebowania, będzie karany ciężkim więzieniem (Zuchthaus) lub więzieniem (Gefängnis). W szczególnie ciężkich przypadkach może zostać wymierzona kara śmierci”.

${ }^{13} \S 244$ StGB: „Kto cudzą rzecz ruchomą zabiera innej osobie w zamiarze, aby ją bezprawnie przywłaszczyć, będzie za kradzież karany więzieniem”. 
W postępowaniu przed sądem specjalnym oskarżony przyznał się do takiego postępowania i wyjaśnił, że bezprawnie sprzedawał mięso bez kartek osobom ubogim.

Sąd specjalny, który wydał wyrok skazujący oskarżonego zum Tode, pominął całkowicie znamię przypisanego mu przestępstwa, jakim była „złośliwość” (Böswilligkeit) działania opisanego $\mathrm{w} \S 1$ Kriegswirtschaftsverordnung.

Sprawa trafiła do Justizministerium w Berlinie, gdyż skazany miał status Volksdeutscha, a postępowanie o ułaskawienie, o którym decydował minister sprawiedliwości Rzeszy, wszczynano z urzędu. Do wyroku została dołączona negatywna opinia składu sędziowskiego co do racji ewentualnego ułaskawienia. Stanowisko (Stellungnahme), z datą 28 lutego 1943 r., że wyrok powinien zostać wykonany, sporządzone przez przewodniczącego Grossmanna, podpisane zostało przez pozostałych członków składu 1 marca 1943 r. z zaznaczeniem, że „odpowiada naszemu zdaniu (entspricht unserer Auffasung)"14.

W kluczowym fragmencie obszernego uzasadnienia swego przekonania sędziowie napisali:

Wobec tego, że skazany uporczywie odmawiał podania swych odbiorców, a jego obrońca w czasie przerwy w posiedzeniu poinformował sąd, że wyłudzone mięso było przekazywane do rąk ewakuowanych Polaków, zachodzi uzasadnione podejrzenie, że mięso to trafiało do małego kręgu polskich odbiorców.

W kwestii uzasadnienia ułaskawienia ministerialny referent (Boltz) w Berlinie napisał w pierwszym zdaniu swego stanowiska z datą 1 marca 1943 r.: „Wyrok faktycznie i prawnie jest bez zastrzeżeń" (Das Urteil ist tatsächlich und rechtlich unbedenklich). Dalej jednakże sformułował krytyczną ocenę wymierzonej kary, podkreślając, że skazany przyznał się do czynu, którego dokonał ,nie z chęci zysku, lecz fałszywie rozumianej dobroduszności”. Zachowanie skazanego miało miejsce rok po wprowadzeniu gospodarki reglamentowanej, a nie wszystkie wykroczenia poza jej reguły należy oceniać - stwierdził - jako ciężkie przypadki. Szczególnie decydujące jest to, że „,według powszechnej praktyki mającej miejsce w czasie czynu skazanego kara śmierci mogła być wymierzona, jeżeli z gospodarki reglamentowanej zostało wyprowadzonych co najmniej 100 cetnarów mięsa”. Tylko w przypadkach, gdy zachodziły okoliczności szczególnie obciążające, a zwłaszcza żądza zysku, uznawano za uzasadnione karanie śmiercią, pomimo mniejszej wagi przedmiotu przestępstwa. Referent zaznaczył, że skazany „wyprowadził tylko 43 i 1/2 cetnara mięsa z gospodarki reglamentowanej”, co miało uzasadniać - postulował - zamianę wymierzonej przez Sondergericht kary śmierci na karę 7 lat więzienia.

${ }^{14}$ Odręczny zamaszysty podpis przewodniczącego Grossmanna na tym dokumencie zapewne oddawał jego wysoką służbową pozycję, jest bowiem groteskowo, co najmniej trzykrotnie, większy od podpisów dwóch pozostałych członków składu. 
Decyzję ministra sprawiedliwości poprzedza w aktach sprawy niepodpisana notatka, sporządzona zapewne przez innego urzędnika:

Skazany (wcześniej polski kapral) wyłudził w sklepie mięsnym swego wuja 61 cetnarów przydziałowego mięsa i sprzedał je bez talonów Niemcom i Polakom. Przedłożenie dla Pana Ministra z 8 marca 1943: Vollstreckung (egzekucja).

Pod tą notatką rozporządzenie (Erlaß):

W sprawie karnej przeciwko skazanemu przez Sondergerich Graudenz 14 stycznia 1943 r. na śmierć Franzowi Bilińskiemu [...] postanowiłem, z mocy udzielonego mi przez Führera pełnomocnictwa, nie czynić użytku z prawa do ułaskawienia, lecz pozostawić wolny bieg sprawiedliwości.

Pod nim wpisano: Berlin i ręcznie „9”, dalej pismem maszynowym: „Marzec 1943. Der Reichsminister der Justiz Th.[ierak]”.

Z treści ostatniego dokumentu znajdującego się w aktach sprawy wynika, że Franz Biliński został stracony na gilotynie w areszcie śledczym w Poznaniu 19 marca 1943 r. o godz 18.32 [,„od doprowadzenia skazanego do przekazania go w ręce kata (Scharfrichter) upłynęło 18 sekund, a następnie do zakończenia egzekucji - 5 sekund"]. Na dokumencie pieczątka prokuratora generalnego w Gdańsku: „Widziałem, 25.03.1943”.

\subsection{Polak handlarzem „najgorszego typu”}

Następny wyrok, poniżej omawiany, ilustruje stosowanie dyrektywy, według której o skazaniu i karze decydowało uznanie oskarżonego za należącego do określonego „typu przestępcy”, nie zaś oparte na racjonalnej wykładni przepisu karnego ustalenie, że jego czyn wyczerpał znamiona tworzące dany typ przestępstwa ${ }^{15}$. Ukazuje on również nieograniczone możliwości posługiwania się karą śmierci przez sędziów sondergerichtów powołujących jako podstawę przepisy „rozporządzenia o prawie karnym dla Polaków i Żydów" z 4 grudnia 1941 r. ${ }^{16}$

Lorenz Ptaschinski, lat 31, Polak, został skazany wyrokiem sądu specjalnego w Grudziądzu z 23 września 1942 r. na karę śmierci ${ }^{17}$. Za podstawę skazania po-

${ }^{15}$ R. Freisler, F. Grau, K. Krug, O. Rietsch, Deutsches Strafrecht, t. 1, Berlin 1941, s. 205, 207. Twierdzenie o „typie przestępcy”, a nie jego czynie, jako decydującym o ukaraniu sformułowała Kieler Schule (G. Dahm, F. Schaffstein).

${ }^{16}$ Rozporządzenie o postępowaniu karnym przeciwko Polakom i Żydom na włączonych terenach wschodnich (Polenstrafrechtsverordnung) z 4.12.1941 r., RGB1. I, s. 759.

${ }_{17}$ Sygn. akt. 3 SG.KLs.52/42, SG.161/42 Archiwum Federalne w Berlinie, DAHL - RJM, IV g 22 Nr. des Aktenbandes $232 / 42$. 
wołano Polenstrafrechtsverordnung Abs. 1. Ziff. $3^{18} \mathrm{w}$ związku z $§ 1$ Kriegswirtschaftsverordnung ${ }^{19}$.

Przewodniczył składowi sędziowskiemu Landgerichtsdirektor Dr. hab. Schönfeld, członkami byli Landgerichtsrat Baron v.d. Osten-Sacken i Landgerichtsrat Wolff. Oskarżał Oberstaatsanwalt Dr. Grunau.

W uzasadnieniu wyroku napisano o oskarżonym, że będąc wykształconym rolnikiem, wspólnie z ojcem prowadził duże (92 morgi) gospodarstwo rolne, które w listopadzie 1941 r. „przydzielone zostało” (wurde zugewiessen) Niemcowi, przesiedleńcowi z Besarabii. Gospodarstwo to oskarżony i jego rodzina „musieli opuścić" (mußten es verlassen $)^{20}$. Po wysiedleniu oskarżony nie miał stałego miejsca zamieszkania, nocował w różnych miejscowościach u krewnych i znajomych, utrzymując się z pokątnego handlu. Niemcom prowadzącym hurtownie w Grudziądzu dostarczał drób, masło, jajka, a w zamian kupował od nich hurtowo papierosy i tabakę, płacąc za nie ceny wyższe niż detaliczne. Uzyskane w ten sposób wyroby tytoniowe sprzedawał z narzutem różnym osobom, w tym trudniącym się pokątnym handlem, lub zamieniał na artykuły żywnościowe. Ogólna wartość towarów zakupionych w hurtowni „Schemberger” w Grudziądzu, do czasu aresztowania oskarżonego w połowie marca 1942 r. - jak napisano - „mogła wynosić 13 000-15 000 marek”. Kupił także w firmie „Brigmann” bez talonu (ohne Bezugschein) cztery worki cukru o wadze $100 \mathrm{~kg}$ każdy, płacąc „,na początku 95, a później 110 marek". Kierownik tej firmy handlowej sprzedał też oskarżonemu bez talonów $8 \mathrm{~kg}$ pieprzu i cztery worki mąki w łącznej cenie 160 reichsmarek, oraz - za podwójną cenę - 300 sztuk pachnącego mydła i 10 kubłów marmolady.

W uzasadnieniu skazania napisano, że „oskarżony jest pokątnym handlarzem najgorszego rodzaju" (Der Angeklagte ist ein Schleichhändler der übelsten Art). W ciągu pół roku „czynem ciągłym uzyskał bez uprawnienia i odsprzedawał dalej wielkie ilości wyrobów tytoniowych, mąki, cukru, pieprzu, a także mięsa, masła i jajek”, przez co ,jako Polak wyrządził szkody Niemieckiemu Narodowi”. Płacił

${ }^{18}$ Przepis ust. I pkt 3 tego rozporządzenia stanowił: „Oni [Polacy i Żydzi - W.K.] będą karani śmiercią, a w mniej ciężkich przypadkach karą pozbawienia wolności, jeżeli przez nienawistną lub podburzającą działalność wykazują wrogą wobec Niemców postawę, w szczególności wyrażają się wrogo o Niemcach, zdzierają lub uszkadzają publiczne obwieszczenia niemieckich władz lub służb, albo jeżeli przez swoje inne zachowania obniżają lub szkodzą poważaniu lub dobru Rzeszy niemieckiej lub niemieckiego Narodu".

19 Treść tego przepisu podano w przyp. 12.

${ }^{20}$ Polaków w powiecie grudziądzkim wysiedlała Schutzpolizei, żandarmeria oraz miejscowi Niemcy. Wysiedlani musieli pozostawić na miejscu cały swój dobytek i kierowani byli na roboty przymusowe do Niemiec lub deportowani do Generalnego Gubernatorstwa. Gospodarstwa rolne, warsztaty rzemieślnicze i mieszkania przejęli Niemcy bałtyccy i nadwiślańscy. Por. M. Wardyńska, Wysiedlenia ludności polskiej z okupowanych ziem polskich włączonych do III Rzeszy w latach 1939-1945, Warszawa 2017, s. 75. Wszelkie próby oporu wysiedlanych Polaków karano śmiercią, przykłady w: W. Kulesza, Odpowiedzialność..., s. 84 i n. 
przy tym zawyżone ceny niemieckim hurtownikom i takich cen żądał. Z pokątnego handlu uczynił sobie oskarżony stałe źródło dochodu, „,nie bacząc na ogół i wymagania wojny, lekceważąc obowiązek posłuszeństwa (Gehorsamspflicht) wobec Niemieckiego Narodu”. Kara śmierci powinna służyć jako przykład „dla krnąbrnego polskiego społeczeństwa na wyzwolonych terenach wschodnich, które próbuje sabotować niemieckie zarządzenia o gospodarce wojennej”. Wyrok wykonany został 12 stycznia 1943 r. po tym, jak „Pan Reichsstatthalter in Danzig-Westpreussen [Albert Forster - W.K.] nie skorzystał z przekazanego mu [przez Hitlera - W.K.] prawa do ułaskawienia"21.

\subsection{Polak zaniedbujący niemieckie krowy}

Kolejny wyrok sondergerichtu w Grudziądzu z 25 listopada 1942 r. $^{22}$, uznający Polaka za zbrodniarza zaniedbującego niemieckie krowy, wydaje się jedynym przypadkiem, w którym prokurator wnosił o ukaranie oskarżonego terminowym obozem karnym, natomiast sąd skazał go na karę śmierci, na co prokurator generalny Gdańska zareagował, wnosząc skargę o nieważność tego wyroku. Jako podstawa skazania powołana została ustawa „o ochronie zwierząt” z 24 listopada 1933 r., jedyna godna uznania, wydana po przejęciu władzy przez NSDAP ${ }^{23}$.

Składowi sędziowskiemu przewodniczył Landgerichtsdirektor dr hab. Schönfeld, członkami byli Landgerichtsrat Baron v.d. Osten-Sacken i Landgerichtsrat Bussejahn. Oskarżał prokurator Beth.

Oskarżonym był 29-letni Johann Nasta, który w 1942 r. pracował przez pięć tygodni jako mleczarz w gospodarstwie Niemca Ewerta, „okrutnie traktując powierzone mu krowy”. Świadkowie zeznali, że oskarżony bił krowy grubym kijem, kopał je, szczuł na nie psa, co sprawiło, że krowy przestały dawać mleko, a jedną z nich przez dłuższy czas niedojoną, i z tego powodu ciężko chorą, trzeba było zaszlachtować. Pozostałe krowy nie były pełnowartościowe, ponieważ przestały dawać cztery miary mleka, lecz dawały tylko dwie lub trzy. $Z$ tego powodu w ciągu miesiąca właściciel miał utracić około 1800 litrów mleka. Natomiast byka oskarżony przywiązał do drewnianego kloca łańcuchem, którego koniec zamocował na pierścieniu nosowym zwierzęcia tak, że ledwo mogło się ono poruszać, a jego nos był stale zaropiały, nie mógł żreć i przez to „bardzo schudł”.

${ }^{21}$ Od 28 maja 1942 r. przysługiwała Forsterowi kompetencja do samodzielnego decydowania w sprawach ułaskawiania Polaków i Żydów. Por. D. Schenk, Albert Forster gdański namiestnik Hitlera. Zbrodnie hitlerowskie w Gdańsku i Prusach Zachodnich, Gdańsk 2002, s. 292.

${ }^{22}$ Sygn. akt. 5/3 Sg.Kls. 68/42, Archiwum Federalne w Berlinie, DAHL - RJM, IV g, Nr. des Aktenbandes 2262/42.

${ }^{23}$ Tierschutzgesetz vom 24. November 1933, RGB1. 1933 I, s. 987. 
Zawarte w aktach sprawy opisy okrutnego postępowania oskarżonego z krowami przekonują czytelnika o karygodności takiego zachowania, które jak napisano, „powodując zranienia i choroby zwierząt, sprowadziły na nie znaczne i długotrwałe cierpienia”. Przyjrzeć się przy tym trzeba kwalifikacji prawnokarnej takiego zachowania. W akcie oskarżenia prokurator przy sondergerichcie zakwalifikował czyn na podstawie dwóch przepisów. Pierwszym był przepis $\S 9$ ust. 1 ustawy o ochronie zwierząt, który przewidywał jako najsurowszą karę dwa lata więzienia ${ }^{24}$. Ponieważ oskarżony był Polakiem, powołany został także Polenstrafrechtsverordnung w tej jego części, w której mowa była o umyślnym uszkodzeniu rzeczy służącej publicznemu pożytkowi ${ }^{25}$. Na rozprawie prokurator zażądał dla oskarżonego kary 6 lat zaostrzonego obozu karnego. Sondergericht skazał go jednakże na karę śmierci, wywodząc w uzasadnieniu, że brak jest podstaw dla uznania zachowania oskarżonego jako przypadku mniej ciężkiego, ponieważ ,z czystej złośliwości i brutalności, wiedząc, że zwierzęta schudły i dawały coraz to mniej mleka, spowodował on niedobór w gospodarce żywnościowej”. Dodano, że „wiedział on, jak ważne są krowy dla gospodarki żywieniowej Narodu Niemieckiego i dlatego muszą być szczególnie pielęgnowane”. Podkreślone zostało, że wyrządzone niemieckiej wspólnocie narodowej szkody ,nie są nieznaczne”. Wyrok wyróżnia się objętością (13 stron maszynopisu) i zaciekłością, z jaką uzasadniano w nim konieczność uśmiercenia Polaka.

W zakresie wymierzonej kary śmierci skargę o nieważność (Nichtigkeitsbeschwerde) ${ }^{26}$ wniósł prokurator generalny w Gdańsku, a wyższy sąd krajowy (Ober-

${ }^{24}$ Tierschutzgesetz stanowił: „§ 1 (1) Zabronione jest zbędne dręczenie lub okrutne znęcanie się nad zwierzęciem". Przepis $§ 9$ przewidywał karę do dwóch lat więzienia i karę grzywny lub jedną z tych kar w przypadku tego, „kto zwierzę niepotrzebnie dręczy lub okrutnie się nad nim znęca”.

${ }^{25}$ Polenstrafrechtsverordnung: „(4) 2 Oni [Polacy i Żydzi - W.K.] będą karani śmiercią, a w mniej ciężkich przypadkach, karą pozbawienia wolności, jeżeli umyślnie niszczą urządzenia niemieckich władz lub stanowisk służbowych bądź rzeczy służące publicznemu pożytkowi”.

${ }^{26}$ Nichtigkeitbeschwerde została wprowadzona przez Verordnung über die Zuständigkeit der Strafgerichte, die Sondergerichte und sonstige Strafverfahrens rechtliche Vorschriften vom 21.2.1940 (RGBl. I, s. 405). Rozporządzenie to uprawniało nadprokuratora Rzeszy do podważenia orzeczenia sondergerichtu w ciągu roku od uprawomocnienia się, ,jeżeli z powodu błędu w zastosowaniu prawa do ustalonych faktów wyrok był niesprawiedliwy" (ungerecht). Rozporządzenie z 13 sierpnia 1942 r. (RGBl. I, s. 508) rozszerzyło zakres stosowania skargi o nieważność na wszystkie wyroki, w których „błędnie zastosowano prawo” i zachodziły „poważne zastrzeżenia co do prawidłowości w ustaleniu faktów”. Skargę o nieważność rozpatrywał Reichsgericht, a od wprowadzenia Polenstrafrechtsverordnung (Ziff. X Abs. 2) w sprawach Polaków i Żydów mógł ją wnosić prokurator generalny landu, kierując sprawę do wyższego sądu krajowego. Z reguły skarga o nieważność prowadziła do zaostrzenia kary wymierzonej w ponownym postępowaniu. Por. H. Schlüter, ,, ... für die Menschlichkeit im Strafmaß bekant...". Das Sondergericht Litzmannstadt und sein Vorsitzender Richter, ,Juristische Zeitgeschichte Nordrhein-Westfalen” 2005, t. 14, s. 132-133.

W akcie oskarżenia przeciwko Otte, prokuratorowi sondergerichtu w Grudziądzu, sformułowany został zarzut, że w wielu wypadkach inicjował on wnoszenie skargi o nieważność (Nichtig- 
landesgericht) w Gdańsku rozpatrzył ją na posiedzeniu 19 stycznia 1943 r. i uwzględnił argument, że oskarżony jako mleczarz nie mógł dobrze wykonywać swoich obowiązków, ponieważ opiekował się 22 krowami mlecznymi, 6 bażantami, cielęciem i bykiem. Oskarżony mówił o tym wyraźnie swemu niemieckiemu zwierzchnikowi, który nie zmniejszył mu jednak obciążenia pracą. Podkreślono też, że 29-letni samotny oskarżony nie mógł w pełni wykonywać swych obowiązków wobec całego stada zwierząt, a pracującym na jego miejscu poprzednikowi, jak i następcy, wydatnie pomagały ich żony. W sprawie - jak stwierdził gdański sąd krajowy - brakuje wystarczających ustaleń sondergerichtu, że skazany ,wykorzystując świadomie brak nadzoru, postępował »z czystej złośliwości (aus Reiner Bosheit)« wobec swego służbowego przełożonego, ze świadomością, że wyrządza przez to szkody w gospodarce żywnościowej Niemieckiego Narodu". Choć dodano, że „z pewnością nie da się wykluczyć tego rodzaju świadomości lub złośliwego zamiaru szkodzenia", to przyjęto, że wymierzona oskarżonemu kara śmierci „przekracza miarę wymaganej pokuty”. Zakwalifikowano jego zachowanie jako przypadek mniejszej wagi, i skazano na karę 5 lat obostrzonego obozu karnego (którego nie miał szansy przeżyć) z pełnym hipokryzji uzasadnieniem, że będzie to ,proporcjonalna pokuta w stosunku do ciężaru czynu i osobowości sprawcy”27.

keitbeschwerde) wyroków tego sądu, skazujących na kary więzienia po to, żeby w powtórzonym postępowaniu przed Wyższym Sądem Krajowym w Gdańsku doprowadzić do wymierzenia podsądnym kary śmierci. Por. W. Kulesza, Odpowiedzialność..., s. 88-89. W referowanej powyżej sprawie prokurator Otte raportował urzędowo przed rozprawą, że przeciwko „mleczarzowi Johannowi Nasta nie przewiduje się Todesstrafe".

Rzadziej stosowanym środkiem podważenia wyroku była skarga nadzwyczajna (Außerordentlicher Einspruch) wprowadzona przez Gesetz zur Änderung der Vorschriften des allgemeinen Strafverfahren, des Wehrmachtstrafverfahrens und des Strafgesetzbuch vom 16.9.1939 (RGB1. I, s. 1841). Przepis art. 2, § 3 Abs. 1 stanowił o uprawnieniu nadprokuratora Rzeszy (Oberreichsanwalt), podlegającego poleceniom Führera, do złożenia sprzeciwu wobec każdego ,prawomocnego wyroku w sprawie karnej [...] w ciągu roku od uprawomocnienia się, jeżeli zachodzą poważne zastrzeżenia co do jego słuszności (Richtigkeit) i konieczność przeprowadzenia nowego postępowania i wyrokowania". Samo wniesienie sprzeciwu unieważniało wyrok, a osobna izba Reichsgerichtu pod przewodnictwem jej prezydenta decydowała o sprawie od początku. Instytucja skargi nadzwyczajnej umożliwiała faktycznie Hitlerowi, jako najwyższemu sędziemu i ostatniej instancji, zatwierdzanie wyroków w drodze powstrzymania się od wydania nadprokuratorowi Rzeszy polecenia wniesienia skargi nadzwyczajnej. Por. H. Schlüter, ,.... für die Menschlichkeit im Strafma $\beta$ bekant...", s. 132. Można przypuszczać, że skarga nadzwyczajna mająca na celu spowodowanie skazania na karę śmierci nie była potrzebna wobec wzrastającej od początku 1942 r. determinacji sędziów sondergerichtów i Trybunału Narodowego (Volksgerichtshof) w ferowaniu takich wyroków. Por. W. Kulesza, Okupacyjny nadburmistrz i sędziowie Sadu Specjalnego w Toruniu (czyli o paradoksach historyczno-prawnych), „Studia Iuridica Toruniensia” 2020, t. 27, s. 135-162.

${ }^{27}$ Według rozporządzenia z 7 stycznia 1942 r. o wykonaniu kary orzeczonej w stosunku do Polaków skazani na karę pozbawienia wolności Polacy nie byli kierowani do więzień, lecz do obozów karnych, w których czas życia przeciętnego więźnia w obozie wynosił średnio sześć miesięcy. Por. W. Kulesza, Sąd..., s. 66, 91. 
To, że skazanego na karę śmierci Polaka pozostawiono przy życiu, nie dezaktualizuje kwestii odpowiedzialności sędziów sondergerichtu za to skazanie, ponieważ stanowiło próbę uśmiercenia go.

\section{ZASADY ODPOWIEDZIALNOŚCI NARODOWOSOCJALISTYCZNYCH JURYSTÓW ZA NAGINANIE PRAWA PRZYJĘTE W REPUBLICE FEDERALNEJ}

2.1. W jurysprudencji Republiki Federalnej nie zostały przyjęte jako podstawa odpowiedzialności karnej jurystów III Rzeszy zasady, na których opierał się wyrok amerykańskiego Trybunału Wojskowego z 4 grudnia 1947 r. zamykający III norymberski proces - prawników ${ }^{28}$. W wyroku tym przytoczona została treść przepisu o przestępstwie naginania prawa ( 336 StGB) jako świadcząca o tym, że „W okresie Republiki Weimarskiej, co najmniej na papierze Niemcy rozwijali cywilizowaną i jasną ideę prawa”, a następnie ,pod panowaniem narodowego socjalizmu nastąpiło postępujące wynaturzenie prawa"29. Przepis prawa niemieckiego o Rechtsbeugung pozostał wiec bez wpływu na ustalenie odpowiedzialności karnej Oskara Rothauga, przewodniczącego sondergerichtu w Norymberdze, którego wyroki skazujące na karę śmierci troje Polaków i Żyda zostały szczegółowo zbadane przez Trybunał, z zaznaczeniem, że „nie zajmował się on zagadnieniem, czy omówione przypadki były sporne w ramach niemieckiego prawa". Trybunał stwierdził natomiast w kwestii skazanych na karę śmierci:

Ponad wszelką rozsądną wątpliwość wynika z materiału dowodowego, że Katzenberger został skazany i stracony, ponieważ był Żydem, a Durka, Strauss i Łopata podzielili ten sam los, ponieważ byli Polakami ${ }^{30}$.

Wyjaśniono dalej w wywodzie:

Poszczególne przypadki, w których Rothaug stosował okrutne i dyskryminujące prawo przeciwko Polakom i Żydom, nie mogą być potraktowane oddzielnie. Istotą skierowanego przeciwko niemu oskarżenia jest to, że brał on udział w narodowym programie prześladowań. Istotą tego, co zostało dowiedzione, jest to, że identyfikował się on z tym narodowym programem i zaangażował się na zewnątrz $\mathrm{w}$ jego realizację. Wziął przez to udział w ludobójstwie ${ }^{31}$.

\footnotetext{
${ }^{28}$ O przebiegu tego procesu: W. Kulesza, Crimen..., s. 21 i n.

29 Ibidem, s. 21.

30 Ibidem, s. 40.

${ }^{31}$ Ibidem, s. 41.
} 
Oskarżeni w procesie przyjęli wspólną linię obrony, którą Trybunał odrzucił, uzasadniając swoje stanowisko:

Oskarżeni twierdzą, że nie można uznać ich za winnych, ponieważ ich postępowanie mieściło się w ramach i miało za podstawę niemieckie ustawy i rozporządzenia. W odniesieniu do zbrodni przeciwko ludzkości przewiduje ustawa Nr 10 Rady Kontroli Niemiec ich karalność bez względu na to, czy zachowania, przez które zostały popełnione, naruszają albo nie naruszają ustawy wewnątrzpaństwowe kraju, gdzie miały miejsce (art. II, 1c) $)^{32}$.

2.2. Ówczesna nauka prawa karnego w Republice Federalnej nie znalazła powodu, dla którego miałaby się jurystyczno-merytorycznie zajmować wyrokiem w sprawie prawników, amerykańskiego Trybunału Wojskowego i ograniczała się do sformułowania trzech zarzutów mających wyrok ten zdyskwalifikować. Pierwszy sprowadzał się do określenia skazania jurystów III Rzeszy aktem „sprawiedliwości zwycięzców - Siegerjustiz". Drugi zarzut polegał na twierdzeniu, że skazanie to łamało podstawowy dla prawa karnego zakaz wstecznego w czasie stosowania jego przepisów (Rückwirkungsverbot). Podniesiono także, jako trzeci zarzut, że nie uwzględniono brakującej oskarżonym prawnikom świadomości bezprawności ich postępowania (fehlenden Unrechtsbewusstsein), a nieświadomość taka wykluczała prawną dopuszczalność ich skazania ${ }^{33}$.

Przyjęte przez wymiar sprawiedliwości Republiki Federalnej zasady prawnokarnego rozliczenia jurystów w służbie III Rzeszy wynikające z warunku dowiedzenia im, że dopuszczali się w swych sędziowskich i prokuratorskich rolach naginania prawa, oraz odrzucenie racji podanych w wyroku, jakim zakończył się norymberski Juristenprozess, spowodowały, że ,prawie wszyscy byli narodowosocjalistyczni prawnicy zostali w następnych latach ponownie przyjęci do służby państwowej" ${ }^{34}$. Początkowo w zachodnich strefach okupacyjnych na naczelne

${ }^{32}$ Ibidem.

${ }^{33}$ E.C. Rautenberg, In Memoriam Nürnberger Juristenprozess: Die Auseinandersetzung mit dem NS - Justizunrecht in den beiden deutschen Teilstaaten, „Goltdammer's Archiv für Strafrecht” 2012, nr 1, s. 34.

${ }^{34}$ Postępowania denazyfikacyjne nie stanęły na przeszkodzie powojennych karier nazistowskich prawników. Łagodna praktyka izb orzekających w tych postępowaniach sprawiła, że członkowie NSDAP uzyskiwali potwierdzenie, że byli politycznie nieaktywni w okresie istnienia III Rzeszy (Mitläufern), a następnie przeszeregowywano ich do kategorii „nieobciążonych”, co umożliwiało powołanie ich na stanowiska w urzędach państwowych, w tym w wymiarze sprawiedliwości. Por. ibidem, s. 41. Mechanizm w istocie „samouwalniania” się od nazistowskiej przeszłości polegał na przedstawianiu w postępowaniach denazyfikacyjnych wystawianych sobie wzajemnie ,świadectw moralności", nazywanych Persilscheine (od nazwy proszku do prania). Por. D. Schenk, Die Post von Danzig. Geschichte eines deutschen Justizmords, Reibek bei Hamburg 1995, s. 217; idem, Poczta Polska w Gdańsku. Dzieje pewnego niemieckiego zabójstwa sadowego, Gdańsk 1999, s. 224. Denazyfikacja zakończyła się w Niemczech Zachodnich niepowodzeniem, ponieważ nie spotkała 
stanowiska w wymiarze sprawiedliwości powoływano adwokatów prowadzących praktykę w III Rzeszy, których można było uznać za mniej obciążonych aniżeli sędziowie i prokuratorzy, lecz później, po zwykle czysto formalnej lustracji, przyjmowano do służby byłych sędziów i prokuratorów, mających doświadczenie z nazistowskiej przeszłości ${ }^{35}$.

2.3.1. Przemilczenie zasad prawa norymberskiego zrodziło pytanie o podstawy odpowiedzialności karnej sędziów ferujących wyroki na podstawie narodowosocjalistycznego prawa. Dziełem Gustawa Radbrucha, ukazującym prawo karne III Rzeszy jako ustawowe bezprawie, jest wypracowana przezeń formuła, która wiodła do konstatacji, że zmierzone wzorcem sprawiedliwości „całe partie narodowosocjalistycznego prawa nigdy nie osiągnęły godności obowiązującego prawa" ${ }^{36}$. Autor ten wskazał także, iż przesłanką odpowiedzialności karnej sędziego za zabójstwo skazanego przezeń na karę śmierci człowieka jest ustalenie, że w treści wydanego wyroku dokonane zostało nagięcie prawa, w rozumieniu przepisu $\S 336$ StGB. Znaczy to, że najpierw trzeba było dowieść sędziemu, iż dokonał on zamierzonego nagięcia prawa, a następnie ustalić skutek takiego czynu, należący do znamion przestępstwa materialnego, jakim jest śmierć skazańca, straconego na mocy naginającego prawo wyroku. Przyjęto, że taka normatywna konstrukcja chroni niezawisłość sędziego, ponieważ tylko nagięcie prawa, będące realizacją podjętego przezeń zamiaru, uzasadnia zarzut popełnienia przestępstwa przeciwko życiu lub wolności skazanej osoby. Twierdzenie to legło u podstaw określenia „przywileju sędziowskiego” (Richterprivileg) polegającego na tym, że subiektywnie niezamierzona realizacja znamienia czynu zabronionego „nagięcia prawa” nie implikowała jego odpowiedzialności za obiektywnie błędny wyrok. Uznano następnie, że ,zamierzone” jest tylko nagięcie prawa z zamiarem bezpośrednim, zaznaczając, że zamiar wynikowy jurysty nie wystarcza dla normatywnego bytu sędziowskiego przestępstwa i jako taki nie otwiera drogi, na której mogłaby zostać ustalona jego odpowiedzialność za prawnokarnie relewantne skutki podjętej decyzji. W ten sposób przepisowi § 336 StGB nadana została „funkcja zamykająca” (Sperrwirkung) drogę prawnego przypisania efektu końcowego, jaką było uśmiercenie skazanego lub pozbawienie go wolności.

się ze społecznym zrozumieniem i nie wywołała skruchy tych, którzy mieli zostać nią objęci, lecz stymulowała wewnętrzny opór wobec alianckich władz okupacyjnych i przekorny upór wynikający z rozżalenia po klęsce narodowego socjalizmu. A w każdym przypadku wywoływała utajoną obronę przed rozliczeniem się z przeszłością. Por. D. Schenk, Auf dem rechten Auge blind. Die braunen Wurzeln des BKA, Köln 2001, s. 128. Do takich samych wniosków dochodzą M. Görtemaker i Ch. Safferling, Die Akte Rosenburg..., s. 72.

35 E.C. Rautenberg, In Memoriam ..., s. 35-36.

${ }^{36}$ O formule Radbrucha wyczerpująco: J. Zajadło, Formuła Radbrucha, Gdańsk 2001, s. 111 in. Por. W. Kulesza, Crimen..., s. 77 i n. 
Deklaracje sędziów III Rzeszy, że ferując wyroki śmierci, pozostawali w przekonaniu o swej powinności stosowania wówczas obowiązującego prawa, uznawano jako wykluczające przypisanie im zamiaru bezpośredniego naginania prawa, co sprawiło, iż żaden z sędziów nie został prawomocnie skazany za pozbawienie życia skazanego przez siebie podsądnego. Jeżeli zatem nie było możliwe dowiedzenie sędziemu, ferującemu wyroki śmierci, że uczynił to z zamiarem bezpośrednim nagięcia prawa, to mniejsze było prawdopodobieństwo skutecznego przeprowadzenia takiego dowodu w przypadku skazania na więzienie.

2.3.2. Wyprowadzony z formuły Radbrucha przez sądownictwo Republiki Federalnej Niemiec pogląd negujący zamiar ewentualny sędziego, jako wystarczający dla bytu odpowiedzialności za naginanie prawa i jego skutki, uzasadniany był potrzebą zagwarantowania sędziowskiej niezależności. Krytykę tego poglądu przeprowadził Fritz Bauer - prokurator generalny Hesji, podnosząc, że „kryminalizacja naginania prawa służy ochronie wszystkich stron procesowych w przeszłości, współczesności i przyszłości, ich równego traktowania, a nie zapewnieniu sędziowskiej niezawisłości" ${ }^{37}$. Jego zdaniem wyłączenie zamiaru wynikowego dokonane przez orzecznictwo ,jest samowolą i stwarza pozory stanu uprzywilejowania". Nie jest zrozumiałe - argumentował cytowany autor „dlaczego nagięcie prawa z zamiarem wynikowym, a więc bądź co bądź aprobowane, ma pozostawać bez znaczenia dla odpowiedzialności sędziego". Stawiał następnie pytanie: ,jak miałyby zostać osądzone bezprawne skazania na karę śmierci, gdyby zabrakło w kodeksie karnym nieużywanego wszak w praktyce jurysdykcyjnej przepisu o naginaniu prawa". Gdyby celem tego przepisu - jak się podnosi - było rzeczywiście zapewnienie sędziowskiej niezawisłości, wówczas obowiązywałby on we wszystkich obszarach „prawnego” postępowania w nazistowskim państwie bezprawia, w którym odrzucona została niezależność sędziów. Stwierdził to zaznacza Bauer - Bundesgerichtshoff, pisząc w wyroku (BGH - 1 StR 639/58):

[...] staraniem posługującej się przemocą narodowosocjalistycznej władzy było systematyczne nadużywanie prawa karnego dostrzegalne od czasu tzw. przechwy-

${ }^{37}$ F. Bauer, Die Humanität der Rechtsordnung. Ausgewählte Schriften, red. J. Perels, I. Wojak, Frankfurt am Main - New York 1998, s. 58. O tym wybitnym prawniku: F. Backhaus, M. Boll, R. Gross (red.), Fritz Bauer der Staatsanwalt. NS-Verbrechen vor Gericht, Frankfurt am Main New York 2014. Jako prokurator generalny Fritz Bauer doprowadził do procesu członków załogi Auschwitz-Birkenau w 1963 r. Por. R. Steinke, Fritz Bauer oder Auschwitz vor Gericht, München Berlin 2014, s. 178 i n.; W. Kulesza, Przedmowa do polskiego wydania [w:] H. Langbein, Auschwitz przed sadem. Proces we Frankfurcie nad Menem 1963-1965. Dokumentacja, Wrocław - Warszawa - Oświęcim 2011, s. VII-XXIX; por. D. Schenk, Generalstaatsanwalt Dr. Fritz Bauer im Widerstreit politischer Interessen [w:] A. Liszewska, J. Kulesza (red.), Pro dignitate legis et maiestate iustitiae. Księga Jubileuszowa z okazji 70. rocznicy urodzin Profesora Witolda Kuleszy, Łódź 2020, s. 77. 
cenia władzy [...]. W obszarze sądownictwa dokonano zamachu na sędziowską niezawisłość i zastąpiono ją kierowaną sprawiedliwością (Justizlenkung) od wewnątrz i zaplanowanym wymuszaniem z zewnątrz ${ }^{38}$.

Brakiem konsekwencji w rozumowaniu Bundesgerichtshofu, na temat uległych władzy sędziów i prokuratorów sądów specjalnych i Trybunału Narodowego było krytykował Bauer - właśnie żądanie, jako warunku ich skazania za Rechtbeugung, dowodu na to, że w sposób zamierzony naginali oni prawo.

Orzecznictwo niemieckich powojennych sądów pozwoliło narodowosocjalistycznym prawnikom, współdziałającym w czynieniu bezprawia w III Rzeszy, na podawanie w każdym przypadku na swą obronę, że dokonywali czynów polegających na narodowosocjalistycznych zabójstwach w zgodzie z własnym sumieniem, nie mając świadomości bezprawia swych zachowań. Ten powtarzany argument obronny stał się praktycznie nie do podważenia, gdyż żaden z nazistowskich prawników nie przyznał się, że postępował świadomie, tj. że „wiedział i chciał” czynić narodowosocjalistyczne bezprawie, naginając prawo w prowadzonych przez siebie sprawach. Tylko w postępowaniach denazyfikacyjnych - zauważył Bauer - można było usłyszeć, że byli oni „ogólnie i stale” przeciwni narodowemu socjalizmowi ${ }^{39}$.

Konsekwencją postawy prawników III Rzeszy, przyjętej generalnie z wyrozumiałością przez powojenny wymiar sprawiedliwości, było to, że niemożliwe stało się ich skazanie za zamierzone naginanie prawa w treści ekscesywnie ferowanych wyroków śmierci. Teza, według której juryści popełniali przestępstwo, uczestnicząc w działalności narodowosocjalistycznej, jeżeli równocześnie dopuszczali się niemożliwego następnie do udowodnienia zamierzonego naginania prawa, prowadziła do „zbudowania ciągłego muru obronnego" sędziów i prokuratorów III Rzeszy. Bauer podkreślał równocześnie, że tłumaczenia prawników III Rzeszy należy rozumieć nie jako potwierdzenie zasady prawnej ich nieodpowiedzialności, lecz „tylko indywidualnie i socjologiczno-psychologicznie” ${ }^{40}$.

2.3.3. Badając przypadki zbrodniczych wyroków, Ursula Solf, prokuratorka w Centrali Badania Zbrodni Nazistowskich w Ludwigsburu, w raporcie o praktyce ścigania prawników za zbrodnie popełnione $\mathrm{w}$ ich zawodowych rolach przekonująco wykazała, że $\S 336$ StGB z użytym w nim pojęciem „naginania prawa” nie przystawał ani do programu kształcenia prawników w III Rzeszy, ani do realiów wykonywania ich zawodu, ponieważ od początku i stale wdrażani byli oni „do rozumienia prawa i ustawy jako woli Führera, której trzeba się domyślić i ją zreali-

\footnotetext{
${ }^{38}$ F. Bauer, Die Humanität..., s. 58.

39 Ibidem, s. 82.

${ }^{40}$ Ibidem, s. 83.
} 
zować"41. Jakże więc sędzia mógłby jeszcze naginać prawo - pytała autorka - jeżeli w swych orzeczeniach, tak jak go nauczono, z oddaniem urzeczywistniał ideologię III Rzeszy, stanowiącą dlań podstawę prawa (Rechtsgrundlage). Sformułowany w orzecznictwie sądowym konieczny warunek odpowiedzialności sędziego, jakim jest dowiedzenie mu, że subiektywnie działał on z zamiarem bezpośrednim, to znaczy „nie tylko musiał znać wszystkie okoliczności, lecz także musiał być świadom, że w swym wyroku dokonuje bezprawia, prowadzić musi do uniewinnień" nazistowskich sędziów. W konkluzji raportu autorka napisała, że sędziemu, który z przekonaniem posługiwał się nazistowskimi ustawami, nie można dziś dowieść, że miał przy tym zamiar nagięcia prawa (Rechtsbeugungvorsatz). Oceniając postępowania karne wszczynane po wojnie przeciwko prawnikom III Rzeszy, dodała, że „próby pociągnięcia nazistowskich sędziów do odpowiedzialności karnej w Republice Federalnej stanowiły tylko usiłowania rozliczenia ich z dokonanego bezprawia, a przecież to oni urzeczywistniali w swych wyrokach politykę Hitlera" ${ }^{42}$. Konstatacja ta dobrze oddaje istotę zagadnienia w aspekcie historycznym i prawnym.

2.3.4. Przeprowadzając krytykę praktyki uwalniania od odpowiedzialności karnej nazistowskich prawników, Heribert Ostendorf cytuje wypowiedź Roberta Kempnera, jednego z oskarżycieli głównych zbrodniarzy wojennych w procesie norymberskim, ukazującą paradoks spowodowany wyprowadzeniem z treści §336 StGB przywileju sędziowskiego (Richterpriwileg): „Dlaczego morderca nie może być ukarany jako morderca, jeżeli jest on prawniczym mordercą? Dlaczego trzeba mówić: jeśli popełnił on sprawiedliwościowy mord, może zostać za to skazany tylko wtedy, gdy równocześnie zostanie mu dowiedzione zamierzone nagięcie prawa" (absichtliche Rechtsbeugung) ${ }^{43}$. Jurystycznie można - zauważa Ostendorf - argumentować też, że przywilej sędziowski odnosi się tylko do obiektywnego aktu orzeczniczego, to znaczy wydanego przez niezależną instancję sądową w prawnie uformowanym postępowaniu, stanowiącego decyzję zorientowaną na zasady sprawiedliwości. A przecież postępowania prowadzone przez Trybunał Narodowy, jak również polityczne sądy specjalne oraz doraźne sądy wojskowe urągały zasadom sprawiedliwego procesu. W praktyce procesy karne prowadzone przed tymi sądami odpowiadały żądaniu ,przywódcy prawa Rzeszy” Hansa Franka: „Narodowosocjalistyczne państwo nie procesuje się z przestępcami, ono ich powala" ${ }^{4}$.

${ }^{41}$ U. Solf, Versuche, Nazi-Richter zur Verantwortung zu ziehen, Ludwigsburg 1995, s. 10 (referat na konferencję ,Justiz im Nationalsozialismus” w Landeszentrale für politische Bildung BadenWürttemberg, 20-22 Januar 1995, s. 10, niepublikowany).

42 Ibidem, s. 49-50.

${ }^{43}$ H. Ostendorf, Die - widersprüchlichen - Auswirkungen der Nürnberger Prozesse auf die westdeutsche Justiz [w:] G. Hankel, G. Stuby (red.), Strafgerichte gegen Menschheitsverbrechen. Zum Völkerstrafrecht 50 Jahre nach den Nürnberger Prozessen, Hamburg 1995, s. 93.

${ }^{44}$ Ibidem. 
2.3.5. Szczegółową krytykę funkcji ochronnej nazistowskich prawników przed odpowiedzialnością, nadaną przepisowi § 336 jako sędziowskiemu przywilejowi (Richterprivileg), mającemu zapewniać ich niezawisłość poprzez przypisanie im skutku wydanego wyroku tylko po uprzednim stwierdzeniu, że nagięli oni prawo, przeprowadził Thomas Vorbaum. Autor pisał z zauważalną w stylistce wywodu nutą pretensji do Radbrucha, że ten niejako „wymyślił” sędziowski przywilej:

W latach 80 . w ramach mojej habilitacji przejrzałem wszystkie dostępne mi podręczniki z okresu do 1945 r. i nie znalazłem ani jednego stanowiska mówiącego o takim przywileju sędziowskim. Mój doktorant Carsten Thiel, który przez kilka lat, w jeszcze szerszym zakresie, badał historię kształtowania się zespołu znamion czynu zabronionego Rechtsbeugung od XIX w., doszedł do takiego samego rezultatu ${ }^{45}$.

Przeto - stwierdza dalej T. Vorbaum - o Radbruchu, „,nawet jeżeli nie jest wynalazcą (Erfinder), to jest pierwszym, który w piśmiennictwie przedstawił taki pogląd", a orzecznictwo sądowe Republiki Federalnej chętnie podchwyciło twierdzenie o funkcji zamykającej (Sperrwirkung) przypisanej do § $336 \mathrm{StGB}$. Pierwsze orzeczenie opierające się na tym twierdzeniu wydał Wyższy Sąd Krajowy w Bambergu, w 1949 r., a następnie było ono powtarzane przez Federalny Sąd Najwyższy $(\mathrm{BGH})^{46}$.

Kolejnym krokiem na drodze ograniczenia odpowiedzialności sędziego było twierdzenie, że koniecznym warunkiem jest, by z zamiarem bezpośrednim nagiął on prawo, co Vorbaum określa krytycznie jako „próg zamiaru” (Vorsatzschwelle). Jeżeli naginający prawo sędzia nie przekroczył owego progu, gdyż nie działał z zamiarem bezpośrednim, tylko ewentualnym, nie może ponosić odpowiedzialności za czyn zabroniony opisany w $§ 336$ StGB. Przeciwko takiemu twierdzeniu Vorbaum podnosi, że jest to swego rodzaju wykładnia contra legem: „We wszystkich podręcznikach do części ogólnej prawa karnego można przeczytać, że jeżeli ustawa nie stanowi inaczej, to zamiar ewentualny (Eventualvorsatz) wystarcza do realizacji zespołu znamion danego przestępstwa" ${ }^{47}$. Następnie wskazał, że co do przestępstwa naginania prawa, to orzecznictwo sądowe zażądało zamiaru bezpośredniego (dolus directus), mimo że ustawa tego nie wymaga. Dlatego „oskarżeni sędziowie mogli z sukcesem powoływać się na to, że wówczas nie byli świadomi bezprawia swych zachowań”48.

${ }^{45}$ T. Vorbaum, Die , strafrechtliche Aufarbeitung” der nationalsozialistischen Justizverbrechen in Nachkriegszeit [w:] M. Görtemaker, Ch. Safferling (red.), Die Rosenburg..., s. 159.

${ }^{46} \mathrm{Na}$ temat kształtowania się orzecznictwa i poglądów piśmiennictwa: W. Kulesza, Crimen..., s. 91 in.

${ }^{47}$ T. Vorbaum, Die ,strafrechtliche Aufarbeitung”..., s. 161.

${ }^{48}$ Ibidem. 
Wnikliwą analizę zagadnienia zamyka Vorbaum, syntetyzując:

Mówiąc krótko: wybrany przez wymiar sprawiedliwości Republiki Federalnej sposób opracowania narodowosocjalistycznych zbrodni, z przeniesieniem przywileju sędziowskiego na nazistowskich sędziów, nie ma uzasadnienia. Sędziowskie zbrodnie zasługują na takie same ich prawnokarne potraktowanie jak inne zbrodnie narodowosocjalistyczne i tak mogłoby to zostać dokonane ${ }^{49}$.

2.4. Przyjęcie przez praktykę pojęć „,przywilej sędziowski” (Richterprivileg) i ,próg zamiaru” (Vorsatzschwelle) było przyczyną tego, że żaden sędzia zawodowy ani wyrokujący w sądach specjalnych, Trybunale Narodowym czy w sądach wojskowych nie został w Republice Federalnej, prawomocnie skazany za żaden $\mathrm{z}$ wielu tysięcy wydanych wówczas wyroków ${ }^{50}$.

Przewodnie stwierdzenie, ujmujące zbiorczo argumenty przyjęte w Republice Federalnej na uzasadnienie zaniechania ścigania prawników narodowosocjalistycznych, zawarte zostało w zdaniu wypowiedzianym na samousprawiedliwienie sędziego Kriegsmarine Hansa Filbingera: „To, co wówczas było prawem, nie może być dziś bezprawiem" (Was damals Recht war, kann doch heute kein Unrecht sein $)^{51}$. Czym w swej istocie było „ówczesne prawo”, stwierdził w swym wykładzie dla sędziów w maju 1939 r. dr Lehmann, sędzia w stopniu generała-majora w Naczelnym Dowództwie Wehrmachtu: „Ustawa jest wyrazem woli kierownictwa państwa jest, jak głosi słynna formuła, najelegantszą formą rozkazu Führera" (Das Gesetz ist der Ausdruk des Willens der Staatsführung, es ist nach einer berümhmten Formulierung die vornehmste Form des Führerbefehls) $)^{52}$. Potwierdził te słowa w norymberskim procesie prawników w 1947 r. Kurt Rothenberger, podsekretarz stanu w ministerstwie sprawiedliwości Rzeszy: „Sędzia jest co do zasady związany ustawami. Ustawy są rozkazami Führera" (Der Richter ist grundsätzlich an die Gesetze gebunden. Die Gesetze sind Führerbefehle) $)^{53}$.

${ }^{49}$ Ibidem, s. 168. Za zabójstwa Niemców skazani zostali współdziałający w wydawaniu decyzji przez sądy doraźne, wprowadzone 15 lutego 1945 r. „,na obszarach zagrożonych przez wroga” - 7 przypadków wymienionych w: W. Kulesza, Crimen..., s. 133-134.

${ }_{50}$ T. Vorbaum, Die ,, strafrechtliche Aufarbeitung”..., s. 158; M. Görtemaker, In eigener Sache. Das BMJ und Seine Beiträge zur Aufarbeitung der NS-Vergangenheit [w:] M. Görtemaker, Ch. Safferling (red.), Die Rosenburg..., s. 35.

${ }^{51}$ M. Görtemaker, In eigener Sache..., s. 36; U. Herbert, Justiz und NS-Vergangenheit in der Bundesrepublik 1945-1950 [w:] M. Görtemaker, Ch. Safferling (red.), Die Rosenburg..., s. 53.

52 D. Schenk, Die Post..., s. 192; idem, Poczta..., s. 198.

${ }^{53} \mathrm{~K}$. Rothenberger został skazany w tym procesie za „wprowadzenie w niemieckim sądownictwie daleko idącej dyskryminacji Żydów i Polaków" na karę 7 lat więzienia. Por. T. Cyprian, Nieznana Norymberga. Dwanaście procesów norymberskich, Warszawa 1965, s. 125, 128. Zwolniony z więzienia w 1950 r., w 1951 r. zaliczony w postępowaniu denazyfikacyjnym do kategorii V - „odciążeni i bojownicy ruchu oporu”, ponieważ pozbawienie go wolności „stanowiło ciężką pokutę za niedowiedzioną winę”. W stanie spoczynku otrzymywał pełne świadczenia. Popełnił samobójstwo 


\section{PRÓBY DOPROWADZENIA DO SKAZANIA NARODOWOSOCJALISTYCZNYCH SĘDZIÓW W REPUBLICE FEDERALNEJ}

3.1. Polska Agencja Prasowa podała 22 sierpnia 1961 r. komunikat zatytułowany „Zbrodniarze w sędziowskich togach”, w którym informowano o ustalonych na podstawie 11 tysięcy dokumentów nazwiskach sędziów sondergerichtu w Łodzi, ze wskazaniem zajmowanych przez nich wówczas w Republice Federalnej stanowisk: dr Horst Neubauer - prezydent sądu spraw społecznych w Essen; dr Wex - dyrektor Sądu Krajowego w Arnsbergu, dr Cramer - dyrektor Sądu Krajowego w Ravensburgu; dr Irschik - prokurator przy Sądzie Krajowym w Ravensburgu; dr Baier - prokurator przy sądzie krajowym w Hamburgu; dr Stumpf - prokurator przy Sądzie Krajowym w Norymberdze. Niemiecka Agencja Prasowa przedrukowała ten komunikat, nadając mu tytuł „Polska oskarża niemieckich sędziów”54.

$\mathrm{W}$ tym samym czasie niemieccy prokuratorzy umarzali postępowania w sprawach sędziów sondergerichtów w okupowanej Polsce, których wyroki przedstawiono na studenckiej wystawie „Ungesünte Nazi Justiz” ${ }^{55}$. Odniesienie się prokuratorów do tych zbrodniczych wyroków zostało niejako wymuszone przez zawiadomienia o popełnieniu przez sędziów, którzy je podpisali, zbrodni naginania prawa w jedności czynu z zabójstwem skazanych ${ }^{56}$. Generalnie przyjęto, że przywilej sędziowski nadal chroni ich przed odpowiedzialnością za wydane i wykonane wyroki śmierci.

Konstrukcja normatywna przywileju sędziowskiego została przedstawiona także w uzasadnieniu wyroku z 6 grudnia 1968 r. Sądu Krajowego w Berlinie uniewinniającego sędziego Otto Rehse, który podpisywał wyroki śmierci obok przewodniczącego Trybunału Narodowego Rolanda Freislera. Odwołanie prokuratury do Federalnego Sądu Najwyższego nie zostało rozpatrzone z powodu śmierci oskarżonego $\mathrm{w} 1969 \mathrm{r}^{57}$

3.2. W 1979 r. wydawało się, że dojdzie do sądowego zanegowania przywileju sędziowskiego w odniesieniu do sędziów Trybunału Narodowego, który był najwyższym politycznym sądem karnym III Rzeszy. Prokurator generalny Berlina

w 1959 r. E. Klee, Das Personenlexikon zum Dritten Reich. Wer was vor und nach 1945?, Frankfurt am Main 2003, s. 511.

${ }^{54}$ H. Schlüter, , ,...für die Menschlichkeit im Strafmaß bekant...”, s. 5.

${ }^{55}$ Szczegółowo o tych umorzeniach: W. Kulesza, Odpowiedzialnośćc..., s. 76 i n. Prokuratura w Düsseldorfie umorzyła postępowanie z uzasadnieniem, że „,z poddanych badaniu kolejnych wyroków Sondergerichtu w Litzmannstadt (Lodz), w których wydaniu współdziałał prezydent senatu Dr. Neubauer nie wynikają żadne punkty zaczepienia [dla twierdzenia - W.K.], że był on winny zamierzonego nagięcia prawa”. Por. W. Kulesza, Sąd Specjalny..., s. 96.

${ }^{56}$ W. Kulesza, Odpowiedzialność..., s. 75.

${ }^{57}$ W. Kulesza, Crimen ..., s. 112. 
polecił bowiem podległej mu prokuraturze poczynienie ustaleń, czy generalnie lub na podstawie konkretnych wyroków, można dowodowo stwierdzić, że Volksgerichthof nie fukcjonował jak ,sąd niezależny, podlegający tylko ustawie”. Dowiedzenie, że Trybunał ten nie był sądem powszechnym (ein ordentliches Gericht) prowadziłoby w konsekwencji do uchylenia orzekającym w nim sędziom przywileju sędziowskiego, wywiedzionego z treści § $336 \mathrm{StGB}$, przy założeniu, iż przepis ten odnosi się tylko do sędziów orzekających w powszechnym i niezależnym sądownictwie.

Powołany w 1934 r. Trybunał Narodowy, jako najwyższy sąd karny, wyrokujący jako pierwsza i ostatnia instancja, wydał w sumie 5200 wyroków śmierci, w sprawach zdrady głównej (Hochverrat) i kraju (Landesverrat), uszkodzenia środków wojskowych (Wehrmittelbeschädigung), wspierania wroga (Feindbegünstigung), szpiegostwa (Spionage) i osłabienia mocy obronnej (Wehrkraftzersetzung). Blisko połowa skazanych pochodziła z krajów okupowanych, a większość z nich stanowili Czesi i Polacy ${ }^{58}$.

W pięcioosobowych składach orzekających Volksgerichtu tylko ich przewodniczący i jeden członek byli zawodowymi sędziami, natomiast trzej ławnicy reprezentowali policję, Wehrmacht i organizacje wchodzące w skład NSDAP. Wszystkich powoływał Adolf Hitler na wniosek ministra sprawiedliwości Rzeszy ${ }^{59}$. Od 1936 r. prezydentem Trybunału był Otto Thierak, który w sierpniu 1942 r. objął stanowisko ministra sprawiedliwości, a w Trybunale zastąpił go Roland Freisler.

Gdy na polecenie służbowe berlińskiego prokuratora generalnego przeprowadzono analizę tysięcy wyroków wydanych przez sędziów Trybunału, których było 398, natomiast prokuratorów - 179, ustalono, że ściganiu podlega 110 żyjących wówczas podejrzanych, z których najmłodszy miał 80, a najstarszy 95 lat ${ }^{60}$. Prawie wszystkie postępowania przygotowawcze zostały umorzone (ostatnie w $1991 \mathrm{r}$.) z powodu niezdolności podejrzanych do udziału w postępowaniu lub braku dowodów w postaci bezprawnych wyroków, w których wydaniu brali udział. Jedynym oskarżonym stał się Kammergerichtstrat w Trybunale Narodowym, dr Paul Reimers, lat 82, któremu zarzucono w akcie oskarżenia z 6 września 1984 r., że w okresie 1943-1945 w 97 przypadkach dokonał lub usiłował dokonać zabójstw z niskich

${ }^{58}$ K. Marxen, H. Schlüter, Terror und „Normalität”. Urteile des nationalsozialistischen Volksgerichtschof: Eine Dokumentation, „Juristische Zeitgeschichte Nordrhein-Westfalen” 2004, t. 13, s. $4,132-133$.

59 Trzeba zauważyć, że liczba ferowanych wyroków śmierci wzrosła po tym, gdy pod Moskwą w grudniu 1941 r. zatrzymana została ofensywa wojsk niemieckich. Do 1940 r. wyroki takie stanowiły 5\%, a w 1942 r. prawie 50\%. Por. H. Benz. H. Graml, H. Weiß (red.), Enzyklopädie des Nationalsozialismus, München 1997, s. 787. O motywacji sędziów ferujących takie wyroki: W. Kulesza, Okupacyjny nadburmistrz...

${ }^{60}$ J. Friedrich, Freispruch für die Nazi-Justiz. Die Urteile gegen NS-Richter seit 1948 r. Eine Dokumentation, Berlin 1998, s. 596. 
motywów. Nie doszło do wydania wyroku w jego sprawie, ponieważ w listopadzie 1984 r., przed rozpoczęciem rozprawy sądowej, popełnił on samobójstwo.

3.3. Bundesgerichtshof zmienił w połowie lat 90 . XX w. regułę chroniącą sędziów w służbie totalitarnego państwa, tłumaczących drakońskie karanie swoim przekonaniem, że czyniąc to, „tylko” stosowali obowiązujące wówczas prawo, bez zamiaru bezpośredniego jego naginania. Zmiana stanowiska nastąpiła dopiero wtedy, gdy przed sądami Republiki Federalnej stanęli sędziowie, którzy naginając prawo, skazywali w NRD przeciwników komunistycznej władzy. W wyroku z 16 listopada 1995 r. BGH skonstatowat:

Przez uległość wobec politycznej władzy „otępiali” sprawcy naginania prawa nie są z tego powodu wolni od kary. [...] Sędzia, który w ślepym posłuszeństwie wobec władzy państwowej przekonany jest, że pozostaje w zgodzie z prawem i ustawą (Recht und Gesetz), gdy ponad granicami ustawowej dopuszczalności realizuje wolę kierujących państwem i przy tym, w przedstawione [w procesie W.K.] sposoby narusza prawa człowieka, nie znajduje się w błędzie rzutującym na jego zamiar ${ }^{61}$.

W wyroku tym BGH dokonał równocześnie samokrytyki, wyznając, że niemiecki wymiar sprawiedliwości „poniósł klęskę w ściganiu nazistowskich sędziów”, której przyczyną było „daleko idące ograniczenie ich odpowiedzialności poprzez wykładnię subiektywnych założeń zespołu znamion czynu zabronionego naginania prawa" 62 .

Powyższa samokrytyczna deklaracja o prawnym i faktycznym zaniechaniu ścigania sędziów III Rzeszy w Republice Federalnej stała się uzasadnieniem podjętej w 2000 r. próby postawienia przed sądem 89-letniego „Dr. H”, którego działalność, jako sędziego sądów specjalnych we Lwowie i Stanisławowie udokumentował w swej publikacji historyk Bernwald Dörner ${ }^{63}$. Kierując się tą publikacją i nowym stanowiskiem BGH, odcinającym się od powojennego zaniechania ścigania nazistowskich sędziów, prokurator Göke z Centrali badania zbrodni narodowosocjalistycznych w Dortmundzie ${ }^{64}$ wszczął śledztwo, w którym zgromadzono 17 wyroków, wydanych w latach 1942-1944, skazujących na karę śmierci 28 osób. Wśród tych wyroków 11 zapadło wyłącznie za „zapewnienie schronienia Żydom” (Unterschlupgewährung an Juden). Sędzia „Dr. H” uczestniczył w ferowaniu 13 wyroków

${ }^{61}$ „Entscheidungen des Bundesgerichtshofes in Strafsachen”, t. 41, s. 337. Omówienie tego wyroku: W. Kulesza, Crimen..., s. 163

${ }^{62}$ Ibidem, s. 221.

${ }^{63}$ B. Dorner, Justiz und Judenmord: Todesurteile gegen Judenhelfer in Polen und der Tschechoslowakei 1942-1944, za: H. Schlüter, ,, ... für die Menschlichkeit im Strafmaß bekant... ”, s. 211.

${ }^{64}$ Zentralstelle im Lande Nordheim-Wesfalen für die Bearbeitung von Nationalsozialistischen Massenverbreschen. 
śmierci, współdziałając z 17 ustalonymi w śledztwie sędziami i prokuratorami sondergerichtu. Prokurator zakwalifikował decyzje sędziów podpisanych pod tymi wyrokami jako morderstwa lub usiłowania dokonania tych zbrodni, uznając, że wypełniony został równocześnie zespół znamion naginania prawa (Tatbestand der Rechtsbeugung). Przesłuchany w październiku 2001 r., w charakterze podejrzanego, będący w stanie spoczynku od 1977 r. sędzia podał, że jako asesor sądu krajowego w Trewirze został wbrew swej woli przeniesiony do sondergerichtu we Lwowie, a w jego pamięci pozostają: dobre mieszkanie, które otrzymał, i dobrzy koledzy. Twierdził przy tym, że nie przypomina sobie wyroków wydanych przez sąd specjalny we Lwowie. W trakcie przeszukania w jego mieszkaniu znaleziono ukryte w skrytce biurka odpisy wydanych przezeń wyroków zgromadzonych w śledztwie i kolejne nieznane dotąd jego wyroki śmierci. Postępowanie przeciwko sędziemu zostało umorzone w 2003 r., przed wniesieniem aktu oskarżenia do sądu, z powodu śmierci podejrzanego. Ustalono, że nie żyje żaden z sędziów uczestniczących w ferowaniu wyroków stanowiących materiał dowodowy dla oskarżenia ${ }^{65}$.

3.4. Prawników III Rzeszy, którzy robili kariery w strukturach władzy, w tym sądowniczej, w Republice Federalnej wymieniano z nazwiska w publikowanej w NRD od 1957 r. „Brunatnej Księdze”66. Listy nazwisk były uzupełniane w kolejnych wydaniach ze wskazaniem aktualnego statusu zawodowego tych jurystów. W wydaniu z 1968 r. wymienieni zostali m.in.: Klaus Wei $\beta$, sędzia sądu specjalnego w Ciechanowie, odpowiedzialny za wydanie 127 wyroków śmierci, po 1945 r. Landgerichtsrat w Oldenburgu; Michałowski, sędzia sądu specjalnego w Bydgoszczy, uczestniczący w wydaniu 58 wyroków śmierci, po 1945 r. Landgerichtsrat w Ravensburgu; obaj przeszli na emeryturę w latach 1962-1963 ${ }^{67}$.

W latach 60 . norymberski wyrok zapadły w procesie jurystów, przemilczany w Republice Federalnej, posłużył wymiarowi sprawiedliwości w Niemieckiej Republice Demokratycznej jako wskazanie sposobu osądzenia prawników III Rzeszy, z zanegowaniem potrzeby oceny wydawanych przez nich wyroków w kategoriach naginania prawa (§ $336 \mathrm{StGB})$.

${ }^{65}$ H. Schlüter, ,, ... für die Menschlichkeit im Strafmaß bekant...”, s. 211.

${ }^{66}$ W kolejnych wydaniach „Brunatnej Księgi”, publikowanej w NRD w latach 1957-1968, wskazywano z nazwiska nazistowskich prawników pełniących po wojnie funkcje w wymiarze sprawiedliwości Republiki Federalnej. Od 1955 r. podano do wiadomości publicznej, także poprzez konferencje prasowe, 1310 nazwisk prawników sądownictwa specjalnego III Rzeszy, którzy w „Niemczech Zachodnich znowu wstępują na urzędy i dochodzą do godności”. Ministerstwu sprawiedliwości Republiki Federalnej przekazano także 1580 wyroków śmierci, w których wydaniu uczestniczyli ci prawnicy, Braunbuch. Kriegs- und Naziverbrechen in Der Bundesrepublik. Staat. Wirtschaft. Verwaltung. Armee. Justiz. Wissenschaft, Nationalrat der Nationalen Front des Demokratischen Deutschland. Dokumentationszentrum der Staatlichen Archivverwaltung der DDR, Berlin 1965, s. 116. Prawdziwość tych informacji nie została zakwestionowana.

${ }^{67}$ Ibidem, s. 120. 


\section{SĘDZIA SONDERGERICHTU W POZNANIU PRZED SĄDEM NRD}

4.1. Postępowanie ze sprawcami narodowosocjalistycznego bezprawia w ramach polityki personalnej w NRD różniło się zasadniczo od wariantu przyjętego w Republice Federalnej. Do 1948 r. przeprowadzono w sowieckiej strefie okupacyjnej radykalne oczyszczenie sądownictwa z tych wszystkich prawników, którzy choćby tylko należeli do NSDAP lub organizacji związanych z tą partią. Taka kategoryczna praktyka denazyfikacji opierała się na założeniu, że nie ma różnicy pomiędzy nominalnymi członkami partii a jej aktywnymi członkami ${ }^{68}$. Utworzenie NRD w 1949 r. związane było z przyznaniem praw wyborczych byłym narodowym socjalistom, uznaniem ich prawa „do działalności zgodnej z fachowymi umiejętnościami”, jednakże z wyłączeniem zatrudnienia „w policji, administracji, straży pożarnej i wymiarze sprawiedliwości”. Powstałą lukę personalną w sądownictwie i prokuraturze starano się wypełnić „nieobciążonymi”, przeniesionymi wcześniej w stan spoczynku sędziami, prokuratorami i adwokatami ${ }^{69}$. Od lutego 1946 r. rozpoczęto przyśpieszone kształcenie nowych kadr: „sędziów ludowych” (Volksrichter) i „ludowych prokuratorów” (Volksanwälte). W 1950 r. prawie 60\% sędziów i 74\% prokuratorów było absolwentami tych kursów, nieposiadającymi dostatecznej wiedzy prawniczej, lecz należącymi w $80 \%$ do SED. W tym czasie pozostawało w służbie tylko 31 sędziów i 5 prokuratorów, którzy wcześniej należeli do NSDAP lub narodowosocjalistycznych organizacji młodzieżowych ${ }^{70}$.

Z nowych kadr wybrano w 1950 r. jako szczególnie zaufanych politycznie 37 sędziów i 18 prokuratorów, członków SED, którym polecono wydanie wyroków w sprawach 3424 jeńców, przekazanych przez sowiecką administrację wojskową. Prawnikom tym powiedziano, że chodzi wyłącznie o osądzenie zbrodniarzy nazistowskich i sprawców zbrodni wojennych, którzy zasłużyli na surowe ukaranie ${ }^{71}$. Procesy te przeprowadzono w zakładzie karnym w Waldheim, z naruszeniem

${ }^{68}$ E.C. Rautenberg, In Memoriam..., s. 39.

${ }^{69}$ Inaczej przedstawiono proces wymiany kadr w sądownictwie we Wschodnich Niemczech, w „Brunatnej Księdze”, w której przytoczono art. IV ustawy nr 4 z 30 października 1945 r. Rady Kontroli Niemiec: „W celu przekształcenia niemieckiego sądownictwa muszą zostać usunięci z ich urzędów sędziowie i prokuratorzy, a także nie mogą zostać do nich dopuszczeni wszyscy wcześniejsi członkowie partii nazistowskiej, którzy aktywnie uczestniczyli w jej działalności, i wszystkie inne osoby, które brały udział w stosowaniu karnych metod hitlerowskiego reżimu". Napisano następnie: „W Niemieckiej Republice Demokratycznej wypełnione zostały te zobowiązania. Prawnicy, którzy byli aktywnymi członkami NSDAP i brali udział w prawodawstwie lub orzecznictwie »Trzeciej Rzeszy«, zostali w $1945 \mathrm{r}$. zwolnieni bez wypowiedzenia. Na ich miejsca wstąpili antyfaszystowscy prawnicy, bojownicy ruchu oporu, robotnicy, chłopi, pracownicy umysłowi. W DDR nie ma żadnego sędziego lub prokuratora, który należał do NSDAP”. Por. Braunbuch..., s. 115.

${ }^{70}$ E.C. Rautenberg, In Memoriam..., s. 41.

${ }^{71}$ Ibidem, s. 40. 
elementarnych zasad prawa karnego materialnego i procesowego, dokonując ryczałtowego osądzenia oskarżonych ${ }^{72}$.

Ze 149 osądzonych w NRD prawników III Rzeszy 130 zostało skazanych w procesach w Waldheim. Nie jest jasne, czy do 19 osądzonych w innych procesach zalicza się, niebudzące zastrzeżeń prawnych, skazanie przez wyższy Sąd Krajowy w Dreźnie w 1947 r. czterech sędziów i dwóch prokuratorów ${ }^{73}$. Przypuszczalnie nie wszystkie wyroki były podawane do publicznej wiadomości, jeden z opublikowanych zostanie poniżej przedstawiony.

4.2. Procesy narodowosocjalistycznych prawników współdziałających w dokonywaniu sądowych zbrodni wykorzystywane były jako dowód na to, że tylko w komunistycznej części kraju realnie ścigani są „faszystowscy krwawi sędziowie”, podczas gdy w Niemczech Zachodnich są oni prawnie i faktycznie chronieni przed odpowiedzialnością karną. Jeżeli jednak pominąć polityczną frazeologię zawartą w uzasadnieniach wyroków i skupić się na zagadnieniach prawnych, to trzeba uznać, że przyjęte w nich rozwiązania kwestii odpowiedzialności sędziów i prokuratorów sondergerichtów za zbrodnie popełnione w ich zawodowych rolach zasługują na respekt. Nie budzą wątpliwości również ustalenia faktyczne szczegółowo zreferowane w uzasadnieniach, choć równocześnie nie znajduje wytłumaczenia, dlaczego z tekstu opublikowanego w „Neue Juztiz” w 1961 r. wyroku skazującego sędziego Sondergerichtu w Poznaniu Johannesa Breyera usunięto jego nazwisko, podając tylko, że „oskarżony” w procesie był członkiem składu orzekającego pod przewodnictwem Karla Bömmelsa, „który dziś ciągle działa jako prezydent senatu Wyższego Sądu Krajowego w Saarbrücken w Zachodnich Niemczech"74. Podano następnie, że oskarżony [Breyer] uczestniczył także w ferowaniu wyroków pod przewodnictwem sędziego dr. Hucklenbroicha ${ }^{75}$ i jako zasiadający w składach przez nich kierowanych współdziałał w skazaniach na karę śmierci łącznie 71 osób.

${ }^{72}$ Szerzej: W. Kulesza, Crimen..., s. 52.

${ }^{73}$ Ibidem, s. 47. Trzy postępowania przed sądem w Halle w latach 1949-1951 (ibidem, s. 50-51).

${ }^{74}$ Rechtsprechung - $\S 211,49$ StGB, Strafrechtliche Verantwortlichkeit faschistischer Blutrichter, BG Schwerin, Urteil vom 14. April 1961 - 1 BS 126/60, „Neue Justiz” 1961, nr 11, s. 394. Wyroki wydane z udziałem Breyera, podpisane przezeń jako członka składu orzekającego sondergerichtu w Poznaniu, opublikował 10 lat wcześniej K.M. Pospieszalski w dokumentalnym opracowaniu Hitlerowskie „prawo” okupacyjne w Polsce, Poznań 1952, s. 376, 379, 383, 385, 386, 392, 402, 404, 406. W „Brunatnej Księdze” podano, że w NRD udało się Breyerowi na kilka lat ukryć w archiwum zakładu przemysłowego. Por. Braunbuch..., s. 115. Odnośnie do dr. Bömmelsa stwierdzono, że dowodowo odpowiada on za wydanie 44 wyroków śmierci i że został pensjonowany we wrześniu 1961 r. Por. Braunbuch..., s. 119. Także niektóre z wyroków zapadłych pod przewodnictwem dr. Bömmelsa opublikował K.M. Pospieszalski (Hitlerowskie..., s. 383, 392, 402, 404, 407).

${ }^{75}$ W „Brunatnej Księdze” wymieniono dr. Hucklenbroischa jako odpowiedzialnego za wydanie 63 wyroków śmierci i podano, że będąc dyrektorem Sądu Krajowego w Wuppertalu, przeszedł 
Udział oskarżonego Johannesa Breyera w wydaniu tych wyroków został udowodniony w sposób niebudzący wątpliwości, ponieważ sąd dysponował kopiami uwierzytelnionych wyroków z jego podpisem (przekazanymi przez Główną Komisję Badania Zbrodni Hitlerowskich w Polsce), które potwierdził sam oskarżony, przyznając się przed sądem, że uczestniczył w ich wydaniu jako członek składu orzekającego $(\text { Beisitzer })^{76}$.

Sąd w Schwerinie, przed którym stanął oskarżony Breyer, napisał o nim w wyroku, że urodził się on w 1891 r. w Talinie w Estonii, studia prawnicze ukończył w Petersburgu w 1918 r., a w 1923 r. przyjęty został do służby w estońskim wymiarze sprawiedliwości, pozostając ,,apolitycznym, obywatelskim jurystą”. W 1939 r. ochotniczo został przesiedlony do Niemiec i z końcem roku skierowany do Poznania, gdzie przeszedł szkolenie uzupełniające jego wiedzę prawniczą, zakończone w sądzie krajowym. Od połowy $1941 \mathrm{r}$. był członkiem składu orzekającego izby karnej tego sądu, którego dyrektor Bömmels przekonywał go stale o „słuszności i konieczności stosowania przeciw polskiej ludności nieludzkich kar"77. Za radą swego zwierzchnika Breyer wstąpił do NSDAP, aby zostać powołanym na stanowisko radcy sądu krajowego (Landgerichtsrat) i równocześnie uzyskać dożywotnią nominację urzędniczą. Od lutego 1942 r. był stałym członkiem składów orzekających Sondergerichtu w Poznaniu.

4.3. We wstępnej części uzasadnienia wyroku zamykającego proces Breyera znajdujemy dobrze odtworzone realia działania sądu specjalnego w Poznaniu „promieniującego" ferowanymi wyrokami na inne sądy w Kraju Warty. Prezydent poznańskiego wyższego sądu krajowego Frobö $\beta$, przy którym działał sondergericht, wygłaszał wykłady dla „stróżów prawa” (Rechtswahrer), instruując sędziów, jak mają swymi wyrokami tworzyć „dzieło odbudowy” na włączonych do Rzeszy terenach wschodnich. Kładł szczególny nacisk na to, że zadaniem sędziów było dokonywanie w wydawanych wyrokach ,syntezy” przepisów niemieckiego prawa pozytywnego zawartych w ustawach i rozporządzeniach z generalnym nakazem Führera (Führerbefehl) zniemczenia (Eindeutschung) kraju, dając przy tym prymat „nakazowi odbudowy” (Aufbaubefehl) niemieckości tego terytorium. Wywodzil, że zadaniem niemieckich sędziów jest posługiwanie się zasadami niemieckiego prawa w celu „stopienia” (Verschmelzung) Warthelandu ze starą Rzeszą (Altreich), co powinno być przeprowadzone w najkrótszym czasie. Zaznaczał, że błędna (falsch) jest każda sędziowska decyzja, która nie uwzględnia ,nakazu odbudowy”. Dlatego

w stan spoczynku w marcu 1963 r. Por. Braunbuch..., s. 119. Wyroki podpisane przez Hucklenbroischa: K.M. Pospieszalski, Hitlerowskie..., s. 376, 377, 383, 385.

${ }^{76}$ Rechtsprechung - $\S 211,49$ StGB, Strafrechtliche Verantwortlichkeit faschistischer Blutrichter..., s. 395.

${ }^{77}$ Ibidem. 
pracę sędziowską - wywodził - musi „przenikać myśl przewodnia o odbudowie”. Inaczej niż w starej Rzeszy, „tu na wschodzie” konieczne jest powoływanie sędziów politycznie myślących, którzy rozumieją, że wydając wyroki, muszą kierować się politycznym rozeznaniem ${ }^{78}$.

4.4. Pierwszy wyrok skazujący na karę śmierci podpisany przez Breyera, jako członka składu sondergerichtu, nosił datę 11 lutego 1942 r. Oskarżonym w sprawie był Mieczysław Przychodski, który 26 stycznia 1942 r., policyjnie aresztowany, został wykorzystany ,do sortowania odzieży zebranej w ramach akcji zbiórki futer i rzeczy wełnianych [co wykonując - W.K.] zabrał parę rękawiczek skórzanych i dwie pary welnianych pończoch, w zamiarze zatrzymania dla siebie tych przedmiotów" "79. Za podstawę skazania podano przepis zarządzenia o ochronie rzeczy zimowych zebranych dla frontu z 23 grudnia $1941 \mathrm{r}^{80}$

Taki sam wyrok z udziałem Breyera zapadł 9 czerwca 1942 r. Oskarżonym był robotnik Wincenty Michalski, któremu nadzorca polecił przewieźć konną furmanką stare materiały bawełniane, zgromadzone w ramach zbiórki, do której Michalski dołożył także własne używane części odzienia. Skazano go na karę śmierci za to, że zabrał z przewożonych rzeczy ,jeszcze nadającą się do używania kamizelkę i dwie czapki z daszkiem" "81. Jako podstawę skazania przyjęto Ziffer I Absatz 3 der Polenstrafrechtsverordnung, uznając, że było to działanie „,szkodzące niemieckiemu dobru narodowemu", i dodając, że zastosowano analogię do myśli przewodniej rozporządzenia o ochronie zbiórki rzeczy zimowych, które ,zmuszało do stosowania takiej kary".

Koniecznością państwową uzasadnił sondergericht z udziałem Breyera skazanie wyrokiem z 13 stycznia 1942 r. na karę śmierci Stanisława Hałasa jako „niebezpiecznego przestępcę z nawyknienia" (przed 1939 r. był 21 razy karany przez polskie sądy za kradzieże) za to, że zabrał butelkę po piwie napełnioną przez siebie terpentyną, która miała mu służyć do czyszczenia rąk, a była przeznaczona do mycia pędzli w zakładzie malarskim jego niemieckiego pracodawcy. Za podstawę skazania przyjęto Ziffer II der Polenstrafrechtsverordnung ${ }^{82}$.

${ }^{78}$ „Ostdeutscher Beobachter” z 13.12.1940 r., cytowany w referowanym wyroku, ibidem, s. 394.

79 Rechtsprechung - $\S 211,49$ StGB, Strafrechtliche Verantwortlichkeit faschistischer Blutrichter..., s. 397. Wyrok ten omawia W. Lemiesz, Paragraf i zbrodnia, Warszawa 1963, s. 37.

${ }^{80} \mathrm{O}$ zarządzeniu Führera dla ochrony zbiórki zimowych rzeczy dla Frontu z 23 grudnia $1941 \mathrm{r}$. szerzej: W. Kulesza, Okupacyjny nadburmistrz...

${ }^{81}$ Wyrok ten omawia W. Lemiesz, Paragraf..., s. 40 i n.

${ }^{82}$ Powołany przepis stanowił: „Polacy i Żydzi będą także karani, jeżeli wykraczają przeciwko niemieckim ustawom karnym lub popełnią czyn, który według myśli przewodniej niemieckiej ustawy na włączonych terenach wschodnich zasługuje na karę, ze względu na istniejącą konieczność państwową". 
W uzasadnieniu wyroku skazującego oskarżonego sędziego Breyera sąd w Schwerinie zaznaczył, że wydawane z jego udziałem wyroki skazujące na karę śmierci odnosiły się wyłącznie do oskarżonych o kradzieże środków żywnościowych i używek o niewielkiej wartości, takich jak ,uzyskane oszukańczymi sposobami jeden funt masła albo słoniny, papierosy i tytoń, a w poszczególnych wypadkach jednej lub wielu tabliczek czekolady"s3. We wszystkich tego rodzaju przypadkach sondergerchit w Poznaniu zajmował stanowisko, według którego „uśmiercenie (Ausmerzung) każdego z oskarżonych jest konieczne”.

Aresztowanie za tego rodzaju zbrodnie prowadziło do śmierci, gdy podejrzani próbowali uwolnić się z policyjnego aresztu. Sąd w Schwerinie zauważył, że ,samo uwolnienie się z policyjnego aresztu nie stanowiło przestępstwa według niemieckiego kodeksu karnego". Pomimo to zostali skazani przez sondergericht w Poznaniu wyrokiem z 24 listopada 1942 r. na karę śmierci „Michael Uniejewski i Tadeusz Chmielewski, po tym jak w lipcu 1942 r. usiłowali zbiec z policyjnego aresztu", aby uchronić się przed transportem do obozu koncentracyjnego w Dachau (zostali ujęci tego samego dnia ${ }^{84}$. Uniejewski został aresztowany za kradzieże, a Chmielewski za rzekomą napaść na Niemca. Próbę ucieczki zakwalifikowano jako zagrożone karą śmierci działanie „na szkodę narodu niemieckiego” w rozumieniu Ziffer I Absatz 3 der Polenstrafrechtsverordnung. Wymierzenie kary śmierci uzasadniono potrzebą odstraszania Polaków przed takimi zachowaniami ${ }^{85}$.

Zeznający przed sądem w Schwerinie świadek Matczyński relacjonował, że zabroniona była sprzedaż Polakom owoców i warzyw, co powodowało kradzieże tych artykułów żywnościowych. Karano śmiercią za kradzież cieląt, krów, warzyw $\mathrm{i}$ innego pożywienia, realizując w ten sposób - jak stwierdził sąd w Schwerinie część barbarzyńskiego planu wyniszczenia polskiego społeczeństwa ${ }^{86}$.

Tak samo karano za spekulację żywnością czy za spekulację samymi tylko kartkami żywnościowymi. Sąd w Schwerinie podkreślił, że w każdym przypadku chodziło o naruszenie przepisów wyrosłych z polityki obrabowania polskiej ludności. Karano śmiercią za kradzieże zarówno rzeczy wartościowych, jak i codziennego użytku, a nawet za rzekomą spekulację nimi.

Jako przykład realizacji tej polityki podano skazanie na karę śmierci, wyrokiem z 24 marca 1944 r., Marii Ojrczyńskiej, córki zamożnego fabrykanta, który pozbawiony całego mienia przez Niemców został wydalony z Poznania do Warszawy, gdzie żył w nędzy. Nie mając żadnych innych środków utrzymania poza małymi, wartościowymi przedmiotami, przesyłał je pocztą córce pracującej na poczcie

${ }^{83}$ Rechtsprechung - $\S 211,49$ StGB, Strafrechtliche Verantwortlichkeit faschistischer Blutrichter..., s. 397.

${ }^{84}$ Ibidem.

85 Ibidem, s. 396.

${ }^{86}$ Ibidem, s. 397. 
w Poznaniu, która w swym mieszkaniu zgromadziła rzeczy przesłane jej w „20-30 paczuszkach", z myślą o ich dalszej sprzedaży i uzyskaniu w ten sposób pieniędzy potrzebnych jej ojcu. Taki stan faktyczny ustalił sondergericht w Poznaniu i uznał, że zachowanie oskarżonej nie jest ,przypadkiem mniejszej wagi”, czym uzasadnił skazanie jej zum Tode. Sąd w Schwerinie skomentował to skazanie jako „kolejny przypadek rzucający światło na jawną rolę tego sądu specjalnego, stanowiącego nazistowski instrument mordowania" ${ }^{87}$.

Das Sondergericht Posen chwalony był w gazecie „Ostdeutscher Beobachter” jako ,ważny w działaniu przeciwko polskim zbrodniarzom i sabotażystom, sprawiedliwy w surowości i oszczędny w litowaniu się nad nimi" ${ }^{88}$.

Wiele wyroków, w których ferowaniu uczestniczył Breyer, zostało wydanych z wstecznym zastosowaniem Polenstrafrechtsverordnung z 4 grudnia 1941 r., głoszącego o karaniu śmiercią każdego Polaka za wszelkie zachowania uznane za stawianie oporu dziełu niemieckiej „odbudowy”. Jako przykład powołany został wyrok z 12 maja 1942 r. skazujący na karę śmierci Stefana Szymelta za czyny popełnione przed wejściem w życie tego rozporządzenia, z następującym uzasadnieniem:

Uznaje się, że oskarżony w sposób zamierzony spowodował uszkodzenie maszyn. Jego nastawienie wrogie wobec Niemczyzny i jego cicha wiara, że Niemcy przegrają wojnę [...] sprawily, że przez powtarzające się uszkadzanie maszyn spowodował on w każdym przypadku zamierzone opóźnienie pracy zakładu produkującego na rzecz obrony Rzeszy, przez co chciał przeszkodzić jej zwycięstwu ${ }^{89}$.

Dalej wymienionych zostało w uzasadnieniu wyroku sądu w Schwerinie sześcioro Polaków skazanych na podstawie Ziffer I Absatz 3 der Polenstrafrechtsverordnung, którzy odważyli się bronić przed dręczeniem ich przez Niemców.

Zreferowany został stan faktyczny sprawy Polki Marii Nowak, która pracując jako sprzątaczka w budynku towarzystwa kolei Rzeszy, była stale szykanowana przez niemieckiego nadzorcę Wessela. Gdy ten kazał jej oddać rzekomo należącą do innej sprzątaczki ścierkę do podłogi i uderzył ją w twarz, Nowak rzuciła mu tę ścierkę w twarz i chwyciła go za włosy. Wyrok skazujący na karę śmierci za działanie „na szkodę Narodu Niemieckiego” został uzasadniony w następujący sposób:

Przy wymiarze kary było decydujące to, że oskarżona przez swoje zachowanie, a w szczególności przez czynną napaść na niemieckiego przełożonego naruszyła ciężko, w sposób przekraczający wszelkie granice, interes Niemieckiego Narodu. Dla rekompensaty naruszonego porządku i siły niemieckiego autorytetu wobec

87 Ibidem.

${ }^{88}$ „Osdeutschen Beobachter” z 5.05.1942 r, cytowany w referowanym wyroku, ibidem, s. 397.

${ }^{89}$ Rechtsprechung - $\S 211,49$ StGB, Strafrechtliche Verantwortlichkeit faschistischer Blutrichter..., s. 396. 
Polaków czyny takie nie mogą być przez Niemców tolerowane. Jest od dawna wiadome i w szczególności wśród Polaków wszędzie omawiane, że każdy Polak, który podnosi rękę na Niemca, będzie, co do zasady, karany śmiercią ${ }^{90}$.

4.5. Kwalifikacja prawnokarna współdziałania sędziego Breyera przyjęta przez sąd w Schwerinie negowała, co do zasady, potrzebę oceny jego zachowania w kategoriach naginania prawa ( 336 StGB) i oparta została bezpośrednio na treści § $211 \mathrm{StGB}^{91}$.

Przeprowadzona argumentacja rozpoczynała się od następująco sformułowanego twierdzenia:

Każda próba przedstawienia orzeczeń karzących śmiercią wydanych przez Sondergericht Posen i w ogóle przez sądy specjalne, jako zgodnych z ustawą i przez to zgodnych z prawem, ponieważ opierały się one na istniejących ustawach, każda próba ograniczenia karalności wydawania takich orzeczeń do przypadków, w których wychodzono ponad treść nazistowskich dyrektyw mordowania, w negatywnym kierunku naginając prawo (Rechtsbeugung), jest pozbawiona wszelkiej podstawy prawnej, a przede wszystkim moralnej. Tego rodzaju próba prowadzi do bezprzykładnego szydzenia z ofiar krwawego wymiaru sprawiedliwości ${ }^{92}$.

Dalej podniesiono, że:

Tak samo jak od każdego obywatela państwa żąda się i żądać będzie można, żeby powstrzymywał się od popełniania przestępstwa, istniał także obowiązek nazistowskich sędziów, wynikający z prawa narodów i prawa wewnętrznego kraju, zaniechania posługiwania się normami rozpoznawalnymi jako zbrodnicze. Bezsporny fakt, że reżim faszystowski użył wszystkich środków propagandowych i administracyjnych, żeby uczynić sędziów uległymi w przeprowadzeniu swych terrorystycznych dyrektyw, nie uwalnia żadnego sędziego od jego obowiązku poszanowania w swym orzecznictwie powszechnie uznanych i wiążących reguł prawa narodów, a w szczególności prawa człowieczeństwa ${ }^{93}$.

Po tych uwagach została dokonana kwalifikacja prawnokarna czynu, pomijająca to, czy sędzia w treści wydanego przez siebie wyroku skazującego na karę śmierci nagiął prawo w rozumieniu $\S 336 \mathrm{StGB}$ :

90 Ibidem.

91 § 211 StGB z 1871 r.: „Kto umyślnie człowieka zabija, ten w razie gdy wykonał czyn ten z zastanowieniem, ulegnie za morderstwo karze śmierci”. Ustawa z 4 września 1941 r. nadała temu przepisowi brzmienie: „§ 211 (I) Morderca podlega karze dożywotniego pozbawienia wolności. (II) Mordercą jest, kto zabija z niskich pobudek lub ze szczególnym okrucieństwem, lub przy użyciu niebezpiecznych środków, lub żeby inny czyn karalny umożliwić lub ukryć”.

92 Rechtsprechung - $\S \S 211,49$ StGB, Strafrechtliche Verantwortlichkeit faschistischer Blutrichter..., s. 398.

93 Ibidem. 
Spowodowanie śmierci człowieka przez sądowe skazanie dokonane przez zastosowanie sprzecznych z prawem narodów zbrodniczych norm państwa Hitlera jest bezprawne, zarówno w rozumieniu prawa narodów, jak i w świetle niemieckiego prawa karnego i kwalifikuje się jako morderstwo - zamierzone zabójstwo popełnione dla urzeczywistnienia faszystowskiej polityki wytępienia i jako takie wynika z niskich motywów, w sensie $§ 211 \mathrm{StGB}^{94}$.

Następnie w treści referowanego wyroku sąd w Schwerinie odniósł się do argumentu podniesionego przez obronę, która wywodziła, że Breyer nie był świadom bezprawności wyroków ferowanych z jego udziałem. Odrzucając ten argument, sąd napisał w uzasadnieniu, że oskarżony potwierdził, iż złożył w czasie studiów egzamin z prawa międzynarodowego i dlatego znane mu były postanowienia konwencji haskiej z 1907 r., zawierające minimalne warunki, jakie musi spełnić władza okupacyjna w traktowaniu ludności cywilnej zajętego terytorium.

Breyer wyjaśniał na swą obronę, że będąc w złym stanie zdrowia, próbował uzyskać przeniesienie z sondergerichtu do wojska, gdzie chciał być tłumaczem, a gdy jego prośba została odrzucona, myślał o popełnieniu samobójstwa ${ }^{95}$. Obrona zbudowała na podstawie wyjaśnień oskarżonego tezę, że znalazł się on w stanie wyższej konieczności i dlatego jako sędzia uczestniczył w wydawaniu zarzucanych mu wyroków. Sąd odrzucił ten argument obrony, wskazując na niekonsekwencję argumentacji, gdyż wcześniej obrońca twierdził, że Breyer nie rozpoznawał bezprawności wyroków wydawanych z jego udziałem. Zanegował również odwołanie się do stanu wyższej konieczności, który miałby wyłączyć winę sprawcy poświęcającego życie wielu ludzi dla ratowania siebie samego ${ }^{96}$. Także zły stan zdrowia i uległość jego publicznie chwalonym zwierzchnikom nie przemawiały - zdaniem sądu - za

94 Ibidem.

${ }^{95}$ Ibidem, s. 399.

96 Trzeba zauważyć, że jest to prawdopodobnie jedyny przypadek tego rodzaju relacji sędziego sondergerichtu złożonej w postępowaniu karnym. G. Wieland pisał o postępowaniach karnych przeciwko nazistowskim prawnikom: „Ani w Niemieckiej Republice Demokratycznej, ani tym mniej w Republice Federalnej i w Berlinie (Zachodnim) w zawisłych postępowaniach tego rodzaju jak dotąd tylko jeden jedyny nazistowski jurysta twierdził, że współdziałał w dokonywaniu aktów bezprawia, ponieważ obawiał się o własne życie. Faktycznie w jego czasach odmowa współdziałania nie powodowała większego zagrożenia, jak tylko przeniesienie, pozostawanie w tyle na drodze awansu, możliwe wcześniejsze przeniesienie na emeryturę lub co najwyżej powołanie do Wehrmachtu". Por. G. Wieland, Besonderheiten der Strafverfahren zu Ahndung von Nazi-Justizverbrechen, „Neue Justiz" 1984, nr 8, s. 53. W Republice Fedralnej przyjęto, wbrew ustaleniom Centrali Ścigania Zbrodni Narodowosocjalistycznych w Ludwigsburgu, że stan wyższej konieczności uchylał winę wykonawców bezprawnych rozkazów egzekucji ofiar, rozstrzeliwanych bez sądu. Vide sprawa dowódcy pododdziału SS Einsatzkommando 16 w Bydgoszczy, oskarżonego o to, że jesienią 1939 r. ,spowodował masowe rozstrzeliwania polskich mieszkańców przez to, że bez wyroku sądowego wydane rozkazy przekazywał dalej”. Sąd Krajowy w Monachium wyrokiem z 1 kwietnia 1966 r. uniewinnił Lölgena, uznając, że znajdował się on w stanie wyższej konieczności, ponieważ obawiał się, że za niewykonanie rozkazu zostanie zesłany do obozu koncentracyjnego. Szerzej: W. Kulesza, Ustalenie 
odstąpieniem od przypisania mu działania z niskich pobudek, co prowadziło do oceny zachowania sędziego w kategoriach zbrodni morderstwa. Uznał, że oskarżony jako członek składu sondergerichtu udzielał pomocy do morderstw dokonywanych przez przewodniczących składów orzekających Bömmelsa i dr. Hucklenbroischa. Stwierdził, że oskarżony dopuścił się pomocnictwa do dokonanego morderstwa w 60 przypadkach i pomocnictwa do usiłowanego morderstwa w 11 przypadkach, w których brak było dokumentów potwierdzających stracenie skazanych ${ }^{97}$.

To, co zdaniem sądu przy wymiarze kary oskarżonemu Breyerowi przemawiało na jego korzyść, to „oparcie się naciskom członków jego rodziny, żeby przeniósł się do Bońskiego Państwa, w którym, jako były krwawy sędzia, byłby faworyzowany i otrzymałby stanowisko $\mathrm{w}$ zachodnioniemieckim wymiarze sprawiedliwości"98. Uwzględniając także wiek oskarżonego (70 lat) i jego zły stan zdrowia, wymierzył mu karę 8 lat więzienia (prokurator wnosił o 12 lat więzienia) ${ }^{99}$.

Oceniając wyrok skazujący Breyera, jako zapadły w procesie odpowiadającym pojęciu fair trial, trzeba pamiętać, że codziennością wymiaru sprawiedliwości w NRD było naginanie prawa przez sędziów i prokuratorów, łamiących zasadę nulla poena sine lege w procesach politycznych, w których skazano - jak się ocenia -250 tysięcy osób ${ }^{100}$. Jednakże prawniczo i historycznie rzecz ujmując, W warunkach totalitarnego państwa komunistycznego nazistowski sędzia Breyer został skazany za sądowe morderstwa dokonane na Polakach, z uzasadnieniem, które trzeba uznać za oparte na prawie i sprawiedliwości. Natomiast w realiach demokratycznej Republiki Federalnej członkowie składu sondergerichtu, z którymi wspólnie dopuszczał się zbrodni, uniknęli odpowiedzialności. W zachodnich Niemczech doszło do „samoamnestionowania” się prawników III Rzeszy, co określono jako skazę (Makel) na obliczu Justycji ${ }^{101}$.

prawdy jako cel postępowania sądowego - refleksje historyczne [w:] H. Czaczkowska, M. Kuciński (red.), Dialog wielokulturowości i prawda, Bydgoszcz 2018, s. 189 i n.

${ }^{97} \mathrm{~W}$ komentarzu podano, że w postępowaniach przeciwko nazistowskim prawnikom twierdzącym, że w czasie narady składu orzekającego sondergerichtu nie głosowali za karą śmierci i dlatego nie są odpowiedzialni za skazanie na taką karę, mocnymi dowodami są dokumenty, w których odnosili się oni negatywnie do ułaskawienia i wypowiadali za wykonaniem wymierzonej kary. G. Wieland słusznie zaznaczył: „Sędzia, który wypowiedział się za wykonaniem wyroku śmierci, nie mógłby twierdzić, że wcześniej głosował przeciwko takiemu skazaniu”. G. Wieland, Besonderheiten..., s. 53.

${ }_{98}$ Rechtsprechung - $\S 211,49$ StGB, Strafrechtliche Verantwortlichkeit faschistischer Blutrichter..., s. 400.

99 Ibidem.

100 S. Zimmerman, Historisches und Politisches Vorverständnis [w:] A. Eser, J. Arnold (red.), Strafrecht in Reaktion auf Systemunrecht. Vergleichende Einblicke in Transitionsprozesse, t. 2, Freiburg im Breisgau 2000, s. 20.

${ }^{101}$ L.M. Peschel-Gutzeit, Aufarbeitung von Systemunrecht durch die Justiz: Anspruch und Wirklichkeit [w:] U. Drobing (red.), Die Strafrechtsjustiz der DDR im Systemwechsel. Partei und Justiz. 


\section{UWAGI KOŃCOWE}

5.1. Tak samo, jak uczyniono to w odniesieniu do prokuratorów III Rzeszy ${ }^{102}$, można $\mathrm{w}$ podsumowaniu przeprowadzonych rozważań przedstawić zasady odpowiedzialności sędziów sondergerichtów, tworzące trzy modele normatywne.

Model pierwszy opiera się na założeniu, że ferowanie wyroków skazujących na karę śmierci, dlatego że oskarżony był Polakiem lub Żydem, stanowiło postać brania przez sędziów udziału w ludobójstwie w rozumieniu ustawy nr 10 Alianckiej Rady Kontroli Niemiec. Stwierdzenie to zostało odniesione w norymberskim procesie prawników do czynów oskarżonego Rothauga.

Drugi model zakłada, że koniecznym warunkiem odpowiedzialności karnej sędziego za zabójstwo skazanego przezeń na karę śmierci człowieka jest dowiedzenie, iż w treści wyroku dokonał on nagięcia prawa, czyniąc to z zamiarem bezpośrednim (§ $336 \mathrm{StGB}$ ). Brak dowodu na to, że sędzia był świadom czynionego bezprawia i chciał je czynić, stanowiło rację uwolnienia go od odpowiedzialności za sądowe morderstwo. Wolni od odpowiedzialności pozostali także prokuratorzy, gdyż niemożliwe było dowiedzenie im, iż z zamiarem bezpośrednim ścigali oni niewinne osoby (§ 344). Żaden prawomocny judykat wydany przez sądy w Niemczech Zachodnich nie potwierdził, że prokurator lub sędzia III Rzeszy popełniali w swych rolach procesowych zbrodnie zabójstwa, za które ponoszą odpowiedzialność karną. Zaznaczyć trzeba, że stan ten wynikał z dokonanego „nagięcia” tez Radbrucha, dokonanego gwoli uwolnienia jurystów III Rzeszy od zarzutu służenia ustawowemu bezprawiu ${ }^{103}$.

Podstawą trzeciego modelu jest zanegowanie racji i potrzeby ustalania, że w zbrodniczym wyroku sędzia nagiął prawo, i zakwalifikowanie jego czynu jako pomocnictwa do morderstwa ( $\S 49$ i 211 StGB). Taką kwalifikację czynu sędziego przyjął sąd w Niemczech Wschodnich, skazując nazistowskiego sędziego Breyera.

5.2. Na nasuwające się pytanie, co sprawiło, że prawnicy III Rzeszy kontynuowali swe kariery, także w ministerstwie sprawiedliwości Republiki Federal-

Mauerschützen und Rechtsbeugung, Berlin 1989, s. 11. Szerzej: W. Kulesza, Przestępcze naginanie prawa przez niemieckie sady specjalne w okupowanej Polsce. Przyczynek do badań [w:] M. Bainczyk, A. Kubiak-Cyrul (red.), Odpowiedzialność państwa za zbrodnie międzynarodowe. Refleksje wokót wystawy „, Rosenburg”, Poznań 2021, s. 25-61; idem, Crime of bending the law (Rechtsbeugung) by German special courts in occupied Poland. A contribution to research [w:] M. Bainczyk, A. Kubiak-Cyrul (eds.), State's Responsibility for International Crimes. Reflections upon the Rosenburg Exhibition, Stuttgart 2021, s. 20-47.

${ }_{102}$ Por. W. Kulesza, Odpowiedzialność..., passim.

${ }^{103}$ Por. W. Kulesza, Lex iniusta non est lex [w:] S. Wojtczak, J. Wyporska-Frankiewicz (red.), Wyzwania współczesnej polityki prawa. Pani Profesor Matgorzacie Król uczniowie i przyjaciele, Warszawa 2022 (w druku). 
nej, odpowiadają powołani na wstępie niniejszego opracowania M. Görtemaker i Ch. Safferling. Zaznaczają oni, że pierwszy minister sprawiedliwości Thomas Dehler i sekretarz stanu Walter Straus sami byli ofiarami dyskryminacji w III Rzeszy. Pomimo to w nowym państwie od 1949 r. mieli swój wkład w kontynuację starej tradycji, stanowiącej hipotekę narodowosocjalistycznego bezprawia, tak samo jak działo się to po wojnie w sądach, prokuraturach i na uniwersyteckich studiach prawniczych ${ }^{104}$. Jako najważniejsze kryteria naboru jurystów do ministerstwa kierowanego przez Dehlera i Strausa przyjęli oni „fachowe kompetencje i ministerialne doświadczenie", pomijając przy tym polityczne obciążenia ponownie powoływanych pracowników, pochodzące z czasów narodowego socjalizmu. Uzasadnieniem takiego postępowania było na pierwszym miejscu dążenie do uzyskania „zdolności pracy" (Arbeitsfähigkeit) ministerstwa, którą - jak uznano - mogły zagwarantować tylko konieczne ku temu fachowe kompetencje współpracowników i ich wcześniejsze doświadczenie, określone jako „skarb” (Schatz an Erfahrungen). Za „mit” uznano kategorię ,,apolitycznych urzędników”, nazywając ją wyimaginowaną figurą myślową, dla której nie ma miejsca w ministerstwie, ponieważ „bliskość polityczna i polityczne doradztwo stanowią jądro zadań ministerialnej administracji”105.

Autorzy wskazują także na specyficzną cechę jurystów, jaką jest wyróżniająca ich wyraźnie spośród innych zawodów zdolność do szybkiego dopasowywania się i wykorzystywania w każdych okolicznościach umiejętności swego rzemiosła spełniania życzeń władzy. W tym sensie „działalność rzemieślnicza” prawników jest niezależna od następujących po sobie reżimów, ponieważ nie dysponują oni sumieniem. Tacy juryści pełnią centralne funkcje w służbie państwowej, współdziałając w tworzeniu ustaw i nie musząc przy tym ponosić bezpośredniej politycznej odpowiedzialności, tak jak i prokuratorzy oraz sędziowie, miarodajnie uczestniczący w stosowaniu prawa. Prawnicy są zatem ,technikami” każdej władzy, wnoszącymi wkład do zabezpieczenia jej panowania i stabilizacji kolejnego politycznego reżimu. W III Rzeszy nastąpiła pełna ,instrumentalizacja” prawników, oparta na ich wewnętrznym przekonaniu lub tylko pragmatycznej woli kariery albo choćby konieczności dopasowania się. Natomiast po 1949 r., w Zachodnich Niemczech, zwykle nie pytano ich o przeszłość. Jak podsumowują autorzy:

Cynicznie można powiedzieć, że tym prawnikom było obojętne, czy formułują przepisy prawa narodowosocjalistycznego, czy normy prawne demokratycznej Republiki Federalnej. Przy tym większość ministerialnych urzędników uznawała siebie samych za pozostających w tradycji „starego urzędnictwa”, sprzed 1933 r., przyjmując zgodnie, że III Rzesza stanowiła tylko fazę czasu, w której kierowano się „błędnie rozumianym pojęciem prawa" ${ }^{06}$.

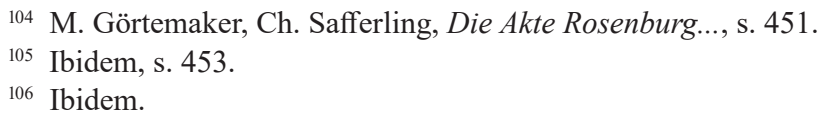




\title{
CRIMINAL LIABILITY FOR JUDICIAL MISCONDUCT OF JUDGES IN THE THIRD REICH IN WEST AND EAST GERMANY
}

\begin{abstract}
The judges of German special courts committed crimes against humanity when they sentenced Poles to the death penalty in occupied Poland during World War II. For instance, a Pole was sentenced to death due to the fact that he had helped displaced Poles by selling them meat, which they had no right to purchase, in his capacity as a shop assistant. The same punishment was meted out to another Pole who was displaced with his whole family from his own farm for living off illegal trade. A Polish milkman was sentenced to capital punishment for neglecting German cows, which resulted in the cows giving less milk. None of the judges who had handed down such judgments was held accountable in the Federal Republic. In communist East Germany, a judge of the Sondergericht in Poznań who participated in sentencing 71 people accused of minor offences to death was sentenced to 8 years in prison. This verdict deserves respect from a contemporary perspective.
\end{abstract}

Keyw ords: transitive justice, judicial misconduct, responsibility of judges, responsibility of prosecutors, Third Reich, $3^{\text {rd }}$ Nuremberg Trial 